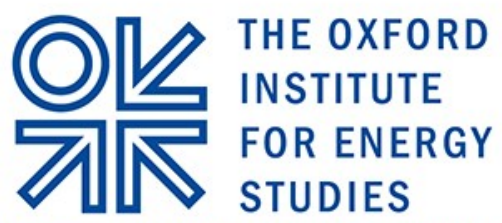

A RECOGNIZED INDEPENDENT CENTRE OF THE UNIVERSITY OF OXFORD

UNIVERSITY OF

OXFORD

March 2014

\section{The Arab Uprisings and MENA Political Instability:}

Implications for Oil \& Gas Markets

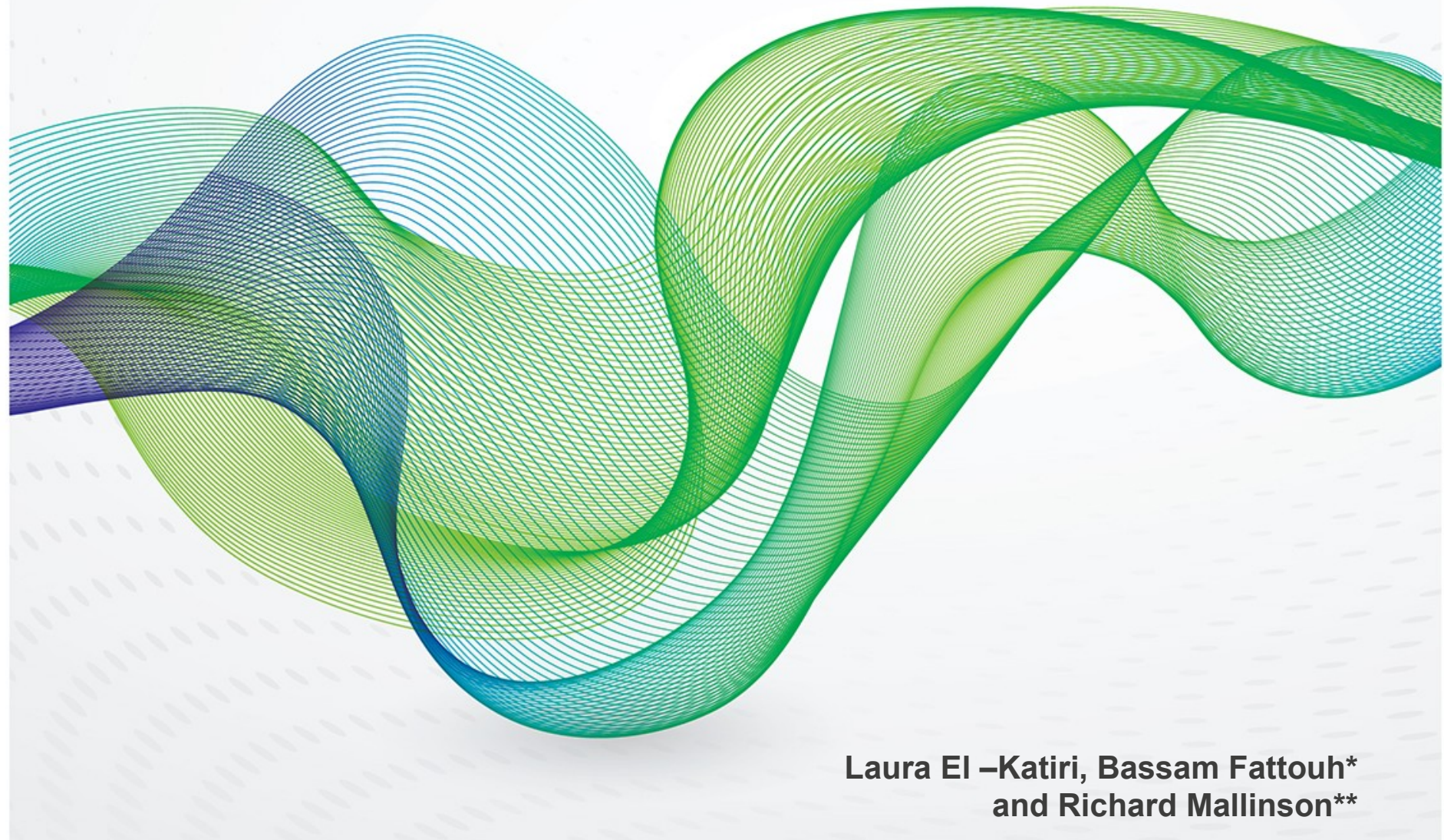


The contents of this paper are the authors' sole responsibility. They do not necessarily represent the views of the Oxford Institute for Energy Studies or any of its members.

Copyright $\odot 2014$

Oxford Institute for Energy Studies

(Registered Charity, No. 286084)

This publication may be reproduced in part for educational or non-profit purposes without special permission from the copyright holder, provided acknowledgment of the source is made. No use of this publication may be made for resale or for any other commercial purpose whatsoever without prior permission in writing from the Oxford Institute for Energy Studies.

ISBN 978-1-907555-98-5 


\section{Contents}

Contents. iii

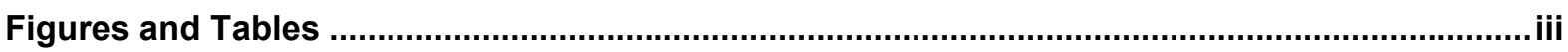

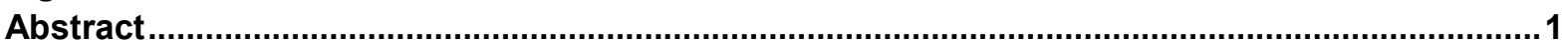

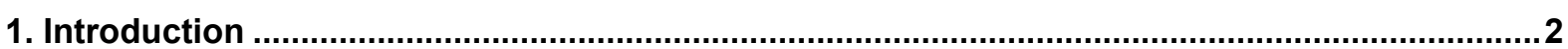

2. Three years of political turmoil in the MENA: a brief background...........................................4

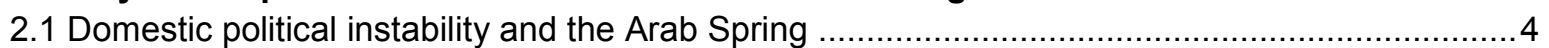

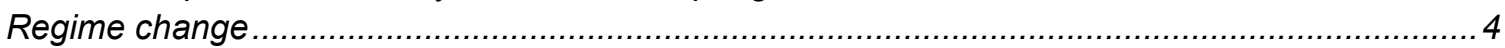

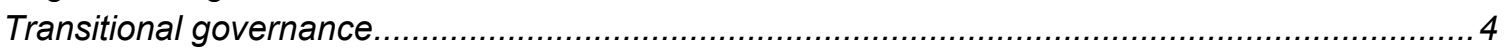

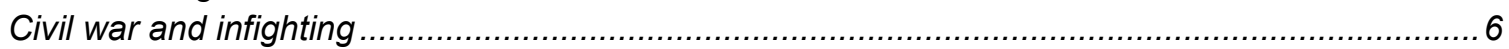

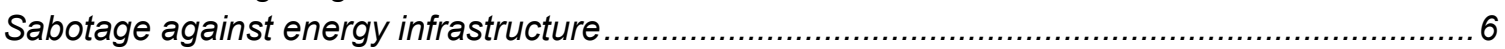

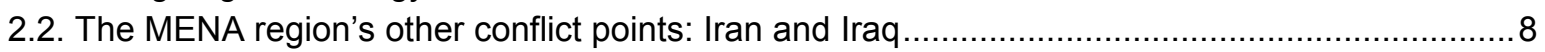

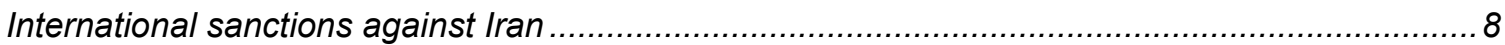

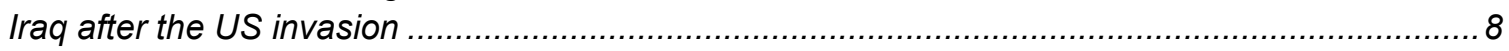

3. Short-term effects of political turmoil on MENA oil and gas supply ......................................10

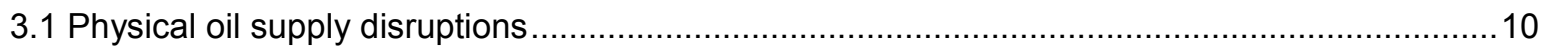

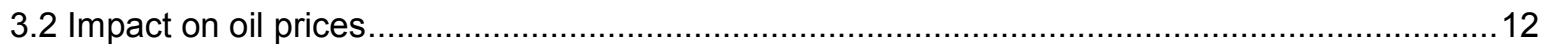

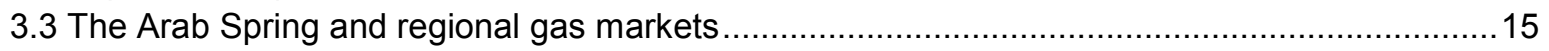

4. The Arab Spring's long-term effects on the MENA's energy sectors ..................................18

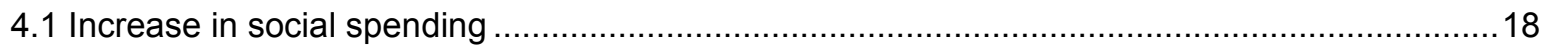

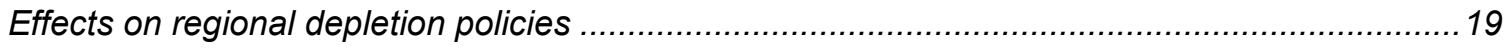

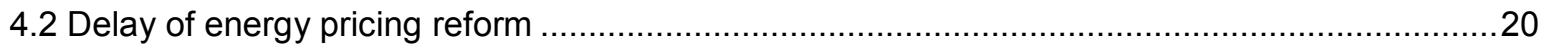

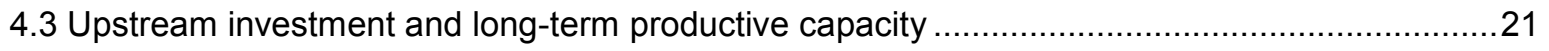

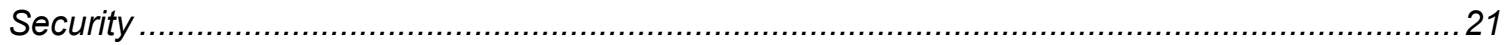

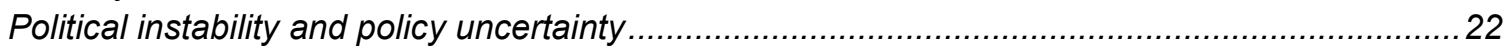

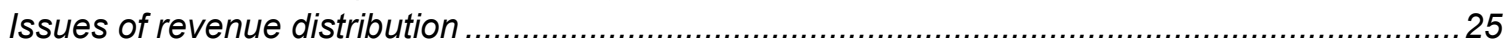

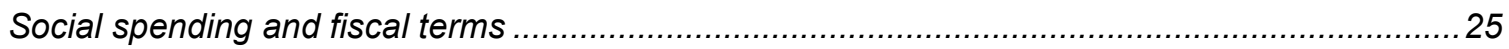

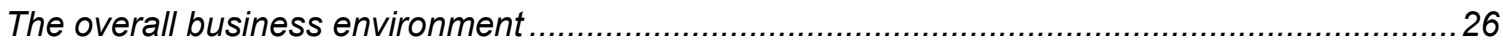

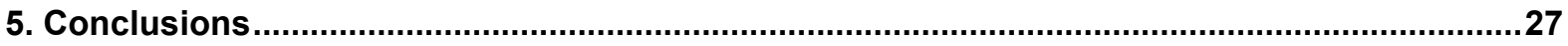

\section{Figures and Tables}

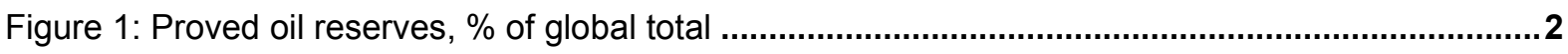

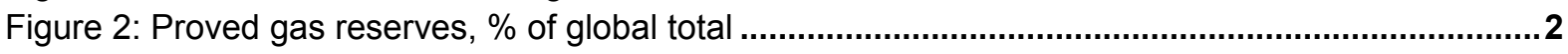

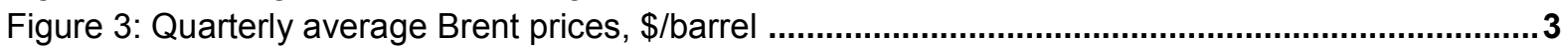

Figure 4: Libyan oil production, million b/d...................................................................................11

Figure 5: Syria and Yemen oil output, million b/d ..........................................................................11

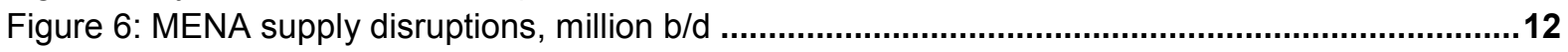

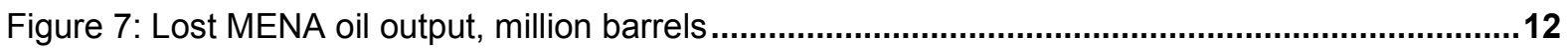

Figure 8: Global supply disruptions by country, million b/d...............................................................13

Figure 9: Brent prices and key MENA events, \$ per barrel ...........................................................14

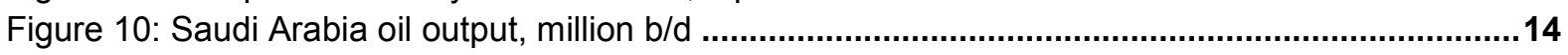

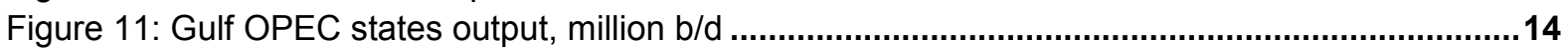

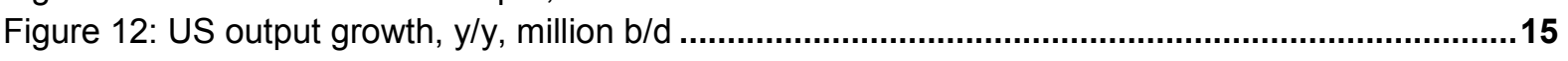

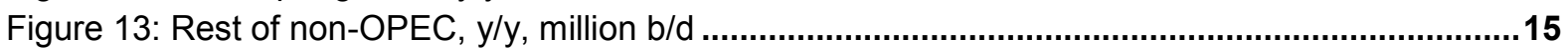

Figure 14: Libyan gas exports, bcm per month.............................................................................16

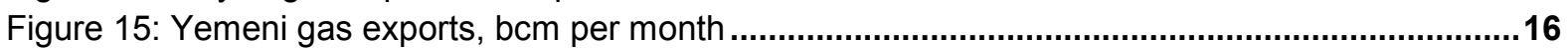

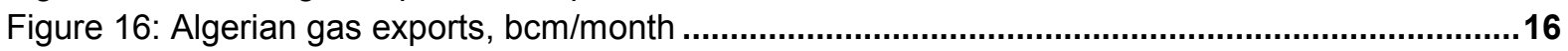

Figure 17: NBP prices in 2013 pence/therm ............................................................................. 16 


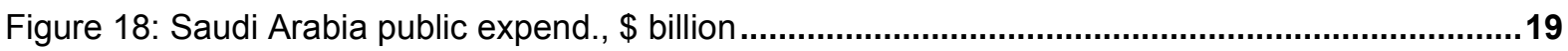

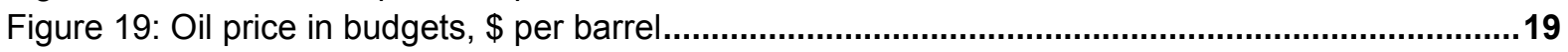

Figure 20: 2012 Retail prices in selected MENA and non-MENA countries, US $\$$ per litre...................21

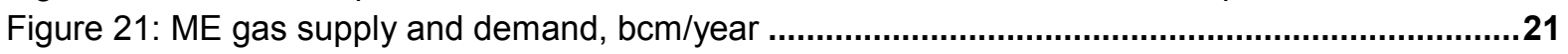

Figure 22: Pace of production recovery after major disruption, million b/d..........................................23

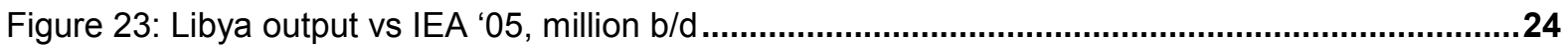

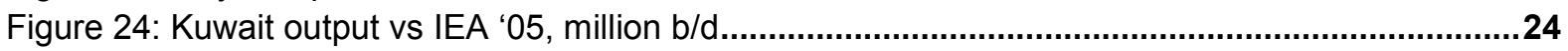

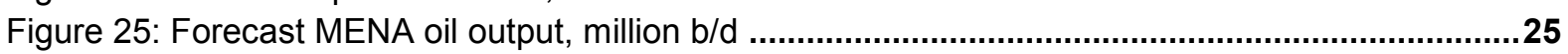

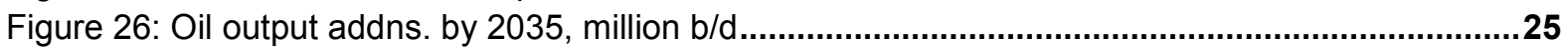

Figure 27: APICORP's Enabling Environment Delphi Survey Results ............................................26

Table 1: Key Political Events in the MENA Region, December 2010 - March 2014...........................5

Table 2: Historic disruptions to oil production ............................................................................12 


\begin{abstract}
The political turmoil that has swept across many parts of the Middle East and North Africa (MENA) since the beginning of the Arab Spring in December 2010 and the tightening of international sanctions against Iran in 2012 have reignited the recurring debate about energy security and the reliability of MENA as an energy supplier. In this paper, we examine the impact of the past three years of political turmoil in MENA on oil and gas markets. We argue that although many disruptions did occur and oil prices did rise, especially following the Libyan revolution in 2011 and when fears of a potential military confrontation between Iran and the USA intensified in early 2012, the short-term effects on oil and gas markets of recent events in the region have been less dramatic than originally feared. The Arab Spring did not destabilize the large Gulf oil and gas producers; the rise in oil price induced by political and geopolitical factors proved to be transient; and oil and gas markets have shown relative resilience in filling the supply gap and in redirecting oil and gas trade flows. Beyond the immediate impact of the past three years of political turmoil in the MENA, however, we argue that it is the more subtle, longterm effects of regional political instability and international sanctions that are likely to leave the most lasting mark on regional oil and gas markets. Potential repercussions are likely to be felt through several years of an unstable regulatory and investment environment, policy uncertainty, deteriorating security, and a lack of much needed energy pricing reform that will impact the long-term production and export capacity of various MENA oil and gas producers, including some of those unaffected directly by the Arab Spring and sanctions.
\end{abstract}



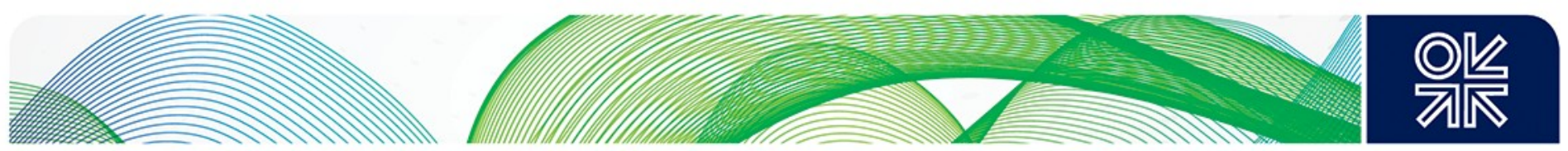

\section{Introduction}

Three years have passed since the Arab Spring began in Tunisia. Several long-serving leaders have left office and ruling elites across the Middle East and North Africa (MENA) ${ }^{1}$ have been shaken to the core. In countries like Libya, Egypt, and Yemen, transitional governments are still grappling with political, social, and economic problems, while the Gulf States have increased social spending as they attempt to temper public discontent. ${ }^{2}$ At the extremes, civil war rages on in Syria, with a heightened risk that the crisis could spill over to its neighbours, upsetting a precarious balance in these countries. In many ways the outcome of the Arab Spring is still in flux three years on. It will be some time before the dust settles and the new political shape of the region is known. In parallel to the Arab Spring, in 2012, the US and the European Union imposed the most comprehensive international sanctions programme yet seen against Iran. In addition, Iraq still looms in the background, continuing to suffer from volatility in both its political environment and security situation.

The spreading instability across MENA has raised widespread concerns about oil supply disruptions and reignited the ever-recurring debate about energy security. ${ }^{3}$ In particular, the region's reliability as an energy supplier, and the efficacy of market mechanisms in coping with supply disruptions, have reemerged as key topics for policymakers. ${ }^{4}$ This should come as no surprise. After all, MENA accounts for 52 per cent of global proved oil reserves and almost a third of global oil production, while holding 47 per cent of the world's proved gas reserves (see Figures 1 and 2). ${ }^{5}$ While concerns about energy security are not new, the context of the debate has fundamentally changed. The global economy is still recovering from the deepest financial crisis since the Second World War; global energy demand dynamics and trade flows continue to shift towards non-OECD countries, mainly to Asia; and the shale gas and tight oil revolution has renewed US aspirations of energy independence or, at least, of a steep reduction in its dependency on imported oil. ${ }^{6}$

Figure 1: Proved oil reserves, \% of global total

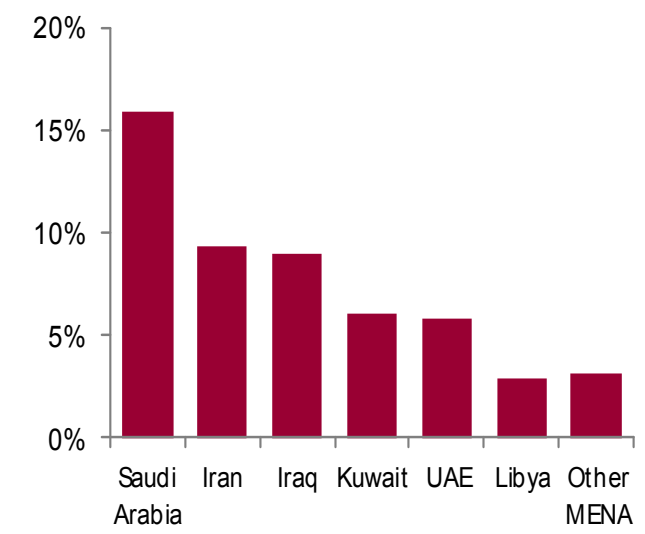

Source: BP (2013)

\section{Figure 2: Proved gas reserves, $\%$ of global total}

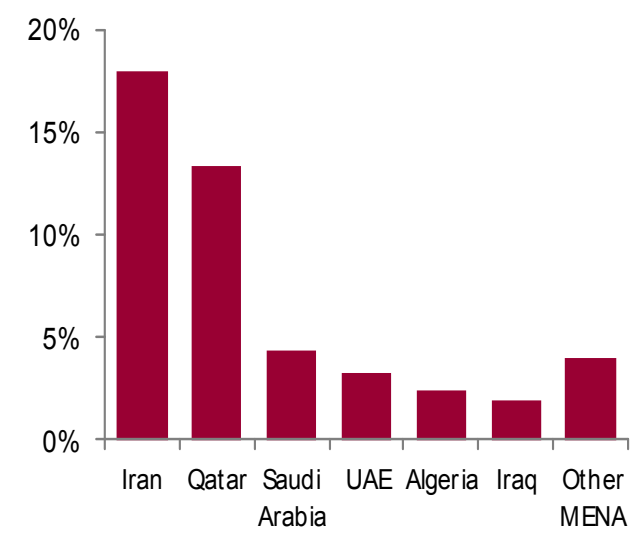

Source: BP (2013)

The many historical precedents of oil disruptions from the region do not help allay energy security concerns. With international oil prices beginning to rise from 2010, there were serious fears among market and political actors that any further increase in prices would put at risk the fragile recovery of the global economy. These concerns proved justified - in the sense that many disruptions did eventually occur and oil prices did rise, especially following the Libyan revolution in 2011, and in early 2012 when fears of a potential military confrontation between Iran and the USA intensified. However, 

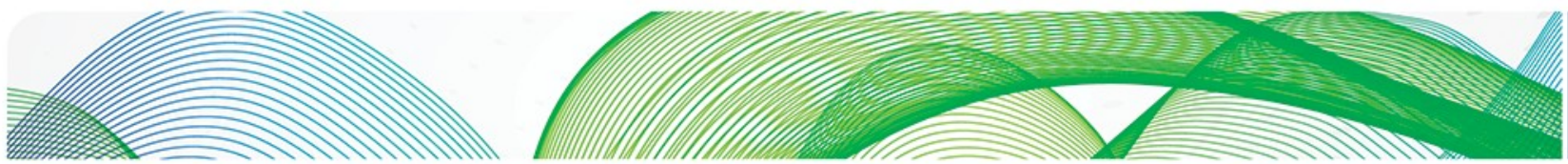

the short-term effects on oil and gas markets of the recent events in the region have been less dramatic than originally feared. The Arab Spring did not spread to the large Gulf oil and gas producers; the rise in oil price induced by political and geopolitical factors proved to be transient; and oil and gas markets have shown relative resilience in filling the supply gap and in redirecting oil and gas trade flows. In fact, one of the remarkable features of oil price behaviour is that despite the various supply shocks and the wide global macroeconomic uncertainty, the quarterly average Brent price has remained relatively stable over the last three years (See Figure 3).

Figure 3: Quarterly average Brent prices, \$/barrel

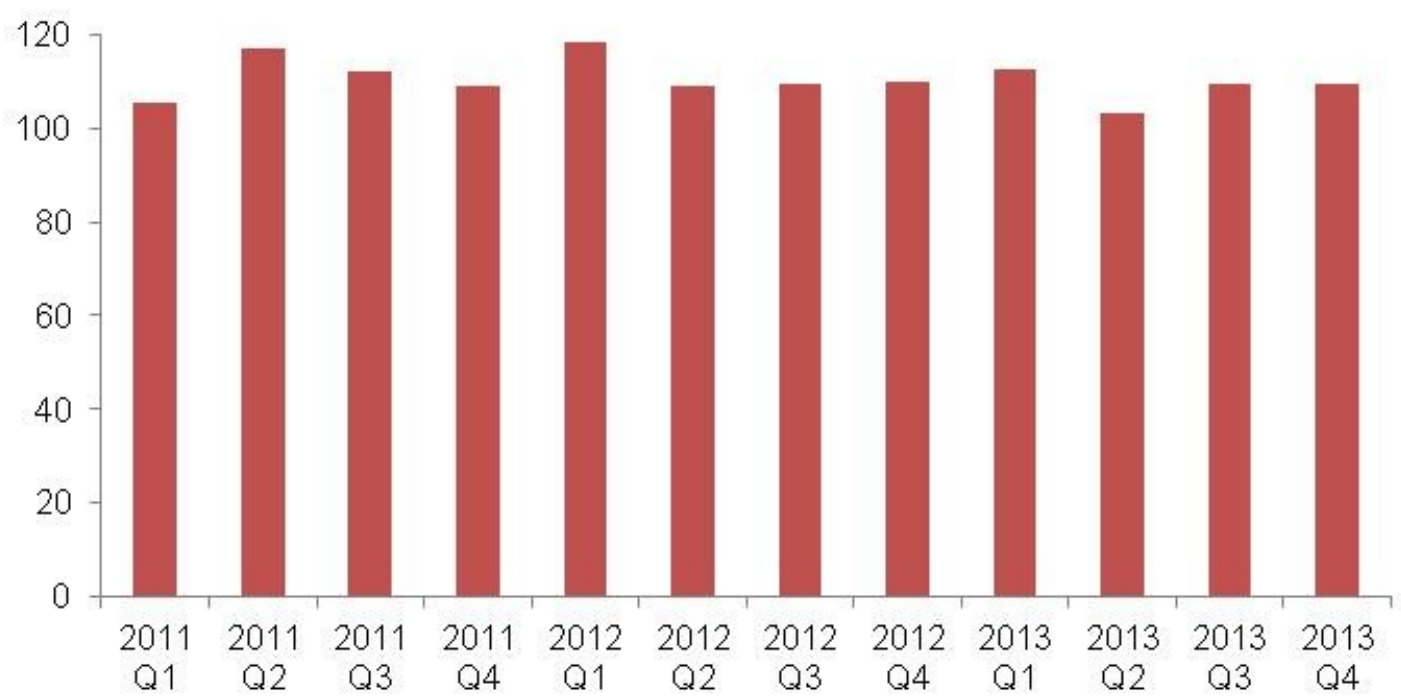

Source: Bloomberg Price Data

Beyond the immediate impact of the past three years of political turmoil in the MENA, however, we argue that it is the more subtle, long-term effects of regional political instability and international sanctions that are likely to make the most lasting mark on regional oil and gas markets. Potential repercussions are likely to be felt through several years of an unstable regulatory and investment environment, policy uncertainty, deteriorating security, and a lack of much needed energy pricing reform that will impact the long-term production and export capacity of various MENA oil and gas producers, including some of those unaffected directly by the Arab Spring and sanctions.

This paper proceeds as follows: Section 2 provides a background of the key political events since December 2010 that have characterized the politically turbulent situation in the MENA, and outlines the way these events have affected the region's energy sectors. Section 3 examines in greater depth the short-term effects of the Arab Spring on the supply of oil and gas from the MENA region to international markets. Section 4 delves into the structural implications of the Arab Spring on the energy sectors of countries in the MENA region, on the investment environment for new upstream production, and on socio-economic policies that are likely to influence preferences related to oil and gas price levels and production policies. Section 5 offers conclusions. 


\section{Three years of political turmoil in the MENA: a brief background}

Political conflicts and wars are certainly not new in the MENA region, nor are disruptions to regional oil flows resulting from such conflicts. The Arab Spring differs from most previous cases of regional conflict, not only in the length of time over which different parts of the region have been affected, but in the way in which its wide-ranging nature has affected most parts of MENA politically, economically, and socially, albeit in vastly different ways. Some of the MENA region's largest oil and gas producers - most importantly the Gulf Cooperation Council ${ }^{7}$ (GCC) states, with the partial exception of Bahrain have remained largely unaffected by the direct impact of the Arab Spring in the form of mass political protest and political regime change. The Arab Spring, furthermore, has coincided with a number of parallel sources of regional supply disruptions, the two most significant of which are the international sanctions against Iran and the continuing fragility of Iraq's domestic situation more than a decade after the US invasion. Below, we 'unpack' these factors in more detail. Table 1 provides a selected overview over the Arab Spring's political timeline, with relevance for oil and gas markets.

\subsection{Domestic political instability and the Arab Spring}

Political instability is one of the most fundamental threats to oil supplies, as it can severely affect countries' production and export capacity over the short and medium term in a variety of ways. In the long term it also induces a high level of uncertainty, undermining companies' investment plans, especially if heightened political instability leads to a deterioration in the security situation. The Arab Spring has affected political stability across the region, both through its actual manifestations in different countries, as well as via the persistent spectre of regional spill-over effects into previously unaffected countries that has hung over the region since 2011.

\section{Regime change}

The Arab Spring has resulted in a number of political regime changes, with far-reaching consequences for medium-term domestic stability and security in the countries concerned. Regime change stood initially at the centre of the Arab Spring movements' agendas in various countries (see Table 1 for an overview over these events):

- Tunisia - long-term President Ben Ali fled the country after weeks of protest following the selfimmolation of Tunisian Mohamed Bouaziz in Sidi Bouzid in December 2010;

- Egypt - Hosni Mubarak in Egypt resigned following three weeks of popular protest;

- Libya - Muammar Gaddafi was killed by rebel forces after fleeing the capital but refusing to resign from power;

- Yemen - Ali Abdallah Saleh stepped down in February 2012, following the escalation of protests in Yemen for several consecutive months.

In each case the protests removed political leaders who had governed their countries for between 24 years (Ben Ali) and 40 years (Gaddafi), leaving behind deep fissures in the political systems of all four countries; while the phase of political infighting between different, regional interests that followed the removal of the political leadership in both Libya and Yemen has turned energy infrastructure into an essential political currency.

\section{Transitional governance}

The more lasting effect of the overthrow of political regimes in North Africa and Yemen has been a prolonged situation of political uncertainty, most clearly visible in the experience of transitional governance in Libya, Egypt, Tunisia, and Yemen. Transitional governments suffer from various sources of contention: the contesting claims by different interest and regional groups who want to shape the nature of the new political order, and a lack of political legitimacy in their own right as a 
non-elected ruling body, having typically short spans of office and an inability to tackle controversial issues that are often left to subsequent, elected governments. In consequence key sectors, including oil and gas, suffer from prolonged planning uncertainty. Rival priorities, together with expectations that governments can formulate quick solutions to issues such as youth unemployment and security, often further erode policymakers' ability to devise more complex policies such as oil sector governance, the investment framework, and fiscal terms. The quick succession of interim and elected governments in Egypt and Libya, on the other hand, has failed to provide policy certainty and stable government in the aftermath of full parliamentary elections. In the Egyptian case this has resulted in the subsequent removal - some would argue this took the form of a military coup - of Egypt's first elected postMubarak head of state, further prolonging political, economic and legal uncertainty for energy companies. ${ }^{8}$

Table 1: Key Political Events in the MENA Region, December 2010 - March 2014

\begin{tabular}{|c|c|}
\hline ate & \\
\hline Dec 2010 & $\begin{array}{l}\text { fire to himself, causes } \\
\text { ntry. }\end{array}$ \\
\hline Jan 2 & $\begin{array}{l}\text { Protests also erupt in Egypt, Yemen, Jordan, Lebanon, and Palestine; Yemeni } \\
\text { oil output declines in subsequent months as a result of protest, domestic fighting, } \\
\text { and frequent sabotage } \\
\text { Tunisian President Ben Ali flees Tunisia after } 24 \text { years in office, replaced by } \\
\text { interim government. }\end{array}$ \\
\hline $5 \mathrm{~J}$ & Egypt; Cairo's Tahrir Square. \\
\hline Feb : & $\begin{array}{l}\text { Protests erupt in Libya, spreading from Benghazi to other Libyan cities; first oil } \\
\text { facilities disrupted in Benghazi; by the summer, production drops to virtually zero } \\
\text { bbls. }\end{array}$ \\
\hline $11 \mathrm{~F}$ & $\begin{array}{l}\text { Protests and police clashes erupt in Bahrain and Iran; Police crackdowns in } \\
\text { Manama (Bahrain) and Algiers (Algeria). } \\
\text { Egypt's President Mubarak resigns after } 30 \text { years in office, replaced by a military- } \\
\text { backed interim government }\end{array}$ \\
\hline a & $\begin{array}{l}\text { Protests erupt in Syria and escalate into civil unrest and fighting across several } \\
\text { Syrian cities over subsequent months; Syrian oil production falls sharply by late } \\
2011 \text { as a result of fighting. } \\
\text { Saudi Arabia and UAE send 1,500 troops to Bahrain to crack down on protesters. }\end{array}$ \\
\hline 20 & $\begin{array}{l}\text { fi is killed by Libyan rebel forces after } 42 \text { years in office, } \\
\text { rim government; oil and gas production rapidly recovers by early }\end{array}$ \\
\hline $\begin{array}{l}28 \quad \text { Nov } \\
2011-11 \text { Jan } \\
2012\end{array}$ & $\begin{array}{l}\text { Parliamentary elections in Egypt, lead to a coalition government of Egyptian } \\
\text { Muslim Brotherhood and the Salafist Al-Nour Party, under presidency of } \\
\text { Mohammed Morsi. }\end{array}$ \\
\hline D & $\begin{array}{l}\text { ar-reaching sanctions aimed at } \\
2012 \text {. }\end{array}$ \\
\hline Feb 2012 & Speculation builds over potential military strike on Iran \\
\hline $12 \mathrm{~F}$ & $\begin{array}{l}\text { years in office, followed } \\
\text { cture. }\end{array}$ \\
\hline & $\begin{array}{l}\text { US and EU oil sanctions against Iran take effect, Iranian oil output gradua } \\
\text { drops by around } 1 \text { million b/d and exports by around } 1.5 \text { million b/d. }\end{array}$ \\
\hline
\end{tabular}




\begin{tabular}{|l|l|}
\hline $\begin{array}{l}\text { Dec 2012- } \\
\text { Jun 2013 }\end{array}$ & New wave of Egyptian protests against Morsi regime. \\
\hline 16 Jan 2013 & $\begin{array}{l}\text { In Amenas attack. Al Qaeda-linked terrorists take } 800 \text { hostages and disrupt } \\
\text { output at an Algerian gas facility in In Amenas; Algerian army raids the site after } \\
\text { four days, leading to death of } 37 \text { foreign hostages, one Algerian worker, and } 29 \\
\text { militants. }\end{array}$ \\
\hline Feb 2013 & $\begin{array}{l}\text { New waves of protests and rising domestic instability in Libya begin to again } \\
\text { disrupt oil and gas production; oil output to declines to less than } 0.25 \text { million b/d } \\
\text { later in the year. }\end{array}$ \\
\hline 3 Jul 2013 & $\begin{array}{l}\text { Egypt's President Morsi ousted from office by Egyptian army less than six months } \\
\text { after his election; protests against Egyptian army follow for months. }\end{array}$ \\
\hline Oct 2013 & $\begin{array}{l}\text { Rising threat of western military strikes on Syria, following August } 2013 \\
\text { chemical attack on Damascus suburb; Russia brokers deal to remove Syrian } \\
\text { chemical weapons. }\end{array}$ \\
\hline Feb 2014 & \begin{tabular}{l} 
Egypt's provisional government resigns, paving the way for new elections. \\
\hline
\end{tabular}
\end{tabular}

Source: Authors; News reporting (various media and issues); MEES (various issues).

\section{Civil war and infighting}

Parts of the Arab region have, moreover, known the Arab Spring not as an effectual time of regime change, but as a time of continued civil infighting between rival power groups and central government. The most bloody civil conflict scenario is in Syria, where initial Arab Spring-style protest has, since March 2011, descended into full-blown civil war, leading to the displacement of almost 2.4 million Syrian citizens. ${ }^{9}$ Syria's civil conflict now incorporates pre-existing cleavages between religiosectarian groups struggling for power with or against the Syrian government; and has led to the shutdown of many of the country's oil and gas production facilities as civil infighting continues. The potential political spill-over effects on Syria's neighbours - including Lebanon and Iraq, both of which have their own pre-existing sectarian conflicts - have further left observers both inside and outside the region concerned about the crisis escalating into a regional conflict: ${ }^{10}$ while the alleged use of chemical weapons against civilians in Syria in August 2013 added considerably to the concern of observers worried about an escalation of the conflict into international intervention in yet another Middle Eastern flash point on the verge of explosion. ${ }^{11}$ The increasingly bloody Syrian conflict has also prompted the country's key oil trading partners (the European Union and Turkey) to impose sanctions against the Syrian government. These sanctions had halted virtually all exports of Syrian crude oil to international markets by the time of writing. ${ }^{12}$

Libya experienced a similar situation of deteriorating domestic security prior to, and in the aftermath of, the removal of the Gaddafi regime. With severe civil infighting between different tribes, militias, cities, and regions, Libya remains torn between different groups; at the time of writing, no end to the domestic turbulence appears to be in sight. Particularly since early 2011, oil production platforms, pipelines, and export infrastructure have become strategic targets for political groups that want to exert influence by either controlling or disrupting them. This has resulted in the frequent shutdown of Libyan production by various groups of protestors in the midst of calls for greater regional autonomy. ${ }^{13}$

\section{Sabotage against energy infrastructure}

A more recent phenomenon, with some implications for the market, particularly in the short term, has been the surge in terrorist attacks and politically motivated sabotage acts against energy infrastructure in several MENA oil and gas producers. We distinguish these kinds of attacks from the general, political instability, which primarily influences a government's decision-making ability and its capability to implement projects, although the two factors are strongly interrelated and are mutually 
reinforcing. Non-state actors opposed to current government policies have, in the past, seen oil and gas infrastructure such as production plants and pipelines as a convenient target. An attack on such infrastructure can disrupt government revenue streams while drawing outside attention to issues of local discontent - such as an inequitable distribution of oil and gas export revenues between regions, tribes, ethnicities, or sects.

While the Arab Spring may be seen as having contributed in one way or another to the use of sabotage as a political weapon in the struggle for political objectives, it is important to distinguish between those protest movements in the Arab streets that characterized the beginnings of the Arab Spring across differing MENA countries, and the use of sabotage by different groups, some of whom pursue objectives that differ widely from the political messages of Arab street protesters. Yemen is an important case in point, having known attacks against its pipeline infrastructure for many years prior to the Arab Spring, while also seeing near-regular attacks against key pipelines over the past three years. ${ }^{14}$ Attacks against Yemen's vulnerable pipeline infrastructure have been ascribed variously to local tribal groups opposed to the Saleh regime, local bandits keen to generate funds from the smuggling of Yemeni oil, and terrorists associated with Al Qaida on the Arabian Peninsula. Such attacks seem largely detached from those groups of Yemeni youth who populated the streets of Yemen's main cities. In Syria, oil and gas fields have played a critical role, as important assets to be seized and fought over by various rebel factions and government forces since the beginning of the civil conflict. In Egypt, too, the country's pipeline gas exports to Israel and Jordan have been subject to several dozen politically motivated attacks on the Sinai Peninsula, aimed at disrupting the Egyptian government's export revenue flow. ${ }^{15}$

Algeria, the scene of perhaps the highest profile attack against energy-related infrastructure in North Africa so far, once more illustrates the way in which many of the past years' attacks against infrastructure in the MENA region in reality bear little direct relation to the political struggles of the Arab Spring itself. The January 2013 attack against Algeria's In Amenas gas production site resulted in the killing of 37 foreign hostages, one Algerian security guard, along with 29 militants. ${ }^{16}$ It was a terrorist attack that had little in common with the frequently more politically organized protest movements of the Arab Spring, nor was it related to any legitimate political opposition group inside Algeria's political system. Affected perhaps more indirectly than directly by the Arab Spring, Algeria has been facing a complex regional geopolitical and security situation stemming from the collapse of three nearby governments (Tunisia, Libya, and Egypt), a proliferation of weapons in the hands of terrorist and insurgent groups in North Africa, and the subsequent mayhem and chaos on its immense southern Saharan borders. Subsequent allegations that the terrorists who attacked the In Amenas site used weapons acquired via Libya and had spent time in the remote south-west of Libya prior to the attack, reflect the destabilizing role that civil strife in one country may have on neighbouring countries. ${ }^{17}$

The proliferation of attacks against energy infrastructure in several MENA countries has raised concerns about whether such attacks are likely to remain relatively isolated episodes with little longterm impact on production and exports from the region. Alternatively, acts of terrorism against energy infrastructure and systematic acts of sabotage might be new realities that have to be taken into account as a more systematic source of operational risk in producing countries such as Yemen, Algeria, and possibly Egypt. Key events such as those at In Amenas are likely to contribute to the rise in production costs - through the cost of security - in many key Arab oil and gas producers over the medium term. They also significantly contribute to the toxic political instability mix that may yet continue to weaken central governance and cast uncertainty on hydrocarbon production and expansion plans over the short to medium term and possibly longer. 


\subsection{The MENA region's other conflict points: Iran and Iraq}

As much as the Arab Spring has been a period defined by new political movements, it has also been a period of conflicts that began well before the onset of the Arab Spring itself. The two most important sources of regional conflict and supply disruptions have undoubtedly been Iran and Iraq; these countries constitute two of the MENA region's largest oil producers outside the Arabian Peninsula and are pivotal players in the regional geopolitical balance of power. While Iraq's continued political fragility has been a source of short-term shocks to the oil market, Iran's deteriorating relations with the international community over its nuclear programme hit a low point in mid-2012 with the enactment of comprehensive US and European sanctions targeting Iranian oil exports. While these events must be seen as being separate to the Arab Spring, they have contributed significantly to the MENA region's oil supply picture during the past few years; they also - in view of the pivotal role played by international intervention and international sanctions on these countries' oil output - provide reasons for exercising caution over any notion that emphasizes internal MENA dynamics alone as being the ultimate source of supply disruptions.

\section{International sanctions against Iran}

The early 2010s have witnessed the withdrawal of large volumes of oil from the market as a result of international sanctions directed against Iran. We estimate a total of 543 million barrels of Iranian oil have been lost between July 2012 and December 2013, which approaches the estimated volume of Iranian oil lost during the time of the Revolution in 1979 (see Table 2 in Section 3 below).$^{18}$ The sanctions imposed on Iran over the Islamic Republic's controversial nuclear programme have further impacted the oil market through a sense of heightened uncertainty. On several occasions in recent years - notably in early 2012 prior to the onset of EU and US sanctions and again around September that year - market participants have become focused on the possibility of military strikes against Iran. These fears caused oil prices to rise for several weeks amidst speculation from some analysts that an outbreak of military conflict with Iran - with the potential involvement of Israel - could lead to a price spike for Brent up to $\$ 200$ per barrel. ${ }^{19}$

The threat of disruption to Gulf oil supply was further heightened in early 2012 by Iranian threats to reciprocate sanctions by disrupting maritime traffic through the Strait of Hormuz, one of the world's most important shipping lanes and a major choke point for the majority of oil and LNG traffic originating from the Eastern Arabian Peninsula (including Saudi Arabia, Iraq, the UAE, and Qatar) ${ }^{20} \mathrm{~A}$ potential total of around 17 million b/d of Gulf-based oil exports (accounting for around 31 per cent of global trade) and some $83 \mathrm{mtpa}$ of Qatari and Emirati LNG (some 33 per cent of global LNG trade) would have been at risk of disruption, constituting a far greater challenge than the withdrawal of any single Gulf producer's exports from oil and gas markets. ${ }^{21}$ Saudi Arabia's spare capacity, together with the IEA's emergency stock release, would prove largely ineffective in the case of a disruption of tanker traffic through Hormuz, as more than two-thirds of oil and some 50 per cent of LNG that passes the Straits of Hormuz is destined for Asian markets where key non-IEA members such as China, India, Indonesia, and Thailand may not have sufficient strategic petroleum stocks. ${ }^{22}$

\section{Iraq after the US invasion}

For more than a decade, Iraq's oil sector has suffered from varying impediments which have prevented the country from reaching its full potential production capacity. The problems associated with much of Iraq's current domestic energy dilemma can be attributed to the almost ten years of civil conflict which followed the 2003 US invasion of Iraq, which in turn followed two major Gulf wars and the imposition of international sanctions against the Saddam regime. ${ }^{23}$ However, while the 2003 Iraq War and its aftermath resulted in over $1,417 \mathrm{mb}$ of lost Iraqi oil output (see Table 2 below), Iraq's oil output had fallen far short of its potential even prior to the 2003 US invasion, due to damage to fields during the Iran/Iraq war in the 1980s and then the international sanctions imposed after the Iraqi 
invasion of Kuwait in 1990/1991, which had significantly reduced Iraq's oil export capacity. ${ }^{24}$ In the aftermath of the 2003 US invasion of Iraq and the toppling of Saddam Hussein's long-term Baath regime, both the country's oil and its natural gas output potential have been severely affected by the country's deteriorating security situation and by continuing political deadlock between different sects, in the presence of existing cleavages between the Sunni-Kurdish, Sunni-Arab, and Shiite-Arab populations, with rival claims over the proceeds of their regional oil and gas reserves. ${ }^{25}$ During the Arab Spring, Iraq has also suffered from smaller disruptions due to a rise in political tensions and spillover from Syria and continuing political deadlock with the country's Kurdish region. ${ }^{26}$ 


\section{Short-term effects of political turmoil on MENA oil and gas supply}

While the final outcome of the Arab uprisings is as yet unknown, one certainty is that the Arab Spring has already earned its place in history as creating one of the oil market's largest disruptions in oil supplies. More than 1,600 million barrels of oil production disruption has been caused over the last three years by outages arising from the Arab Spring and sanctions linked to Iran's nuclear programme. Supply disruptions from the region since December 2010 come second only to oil market losses incurred as a result of the Iraqi invasion of Kuwait in 1990 (see Table 2 below). And unlike previous cases of conflict affecting the MENA region's oil supply - such as the 1950s Suez War, the 1960s Six-Day War, and the 1970s Arab-Israeli War - the Arab Spring has, for the first time, also affected gas markets, albeit to a far lesser degree than oil. Below, we assess the short-term effects of the Arab Spring and Iranian sanctions on oil supply from the MENA region and on oil prices, and then its impact on regional gas markets.

\subsection{Physical oil supply disruptions}

A striking feature of the Arab Spring has been that its actual impact on oil and gas production has varied widely between affected countries. While significant volumes of production were lost in some MENA oil and gas producers, others have seen their energy sectors less directly impacted by popular protest. The most significant short-term impact of the Arab Spring on oil production has undoubtedly been in Libya. This North African OPEC member can produce over 1.5 million b/d and plays an important export role in global oil markets. Libya's output virtually halted in the summer of 2011 as civil war raged across the country, but it returned more quickly than many in the market had anticipated, reaching 1.4 million b/d in early 2012. Rising security concerns and political instability disrupted Libyan production significantly again in 2013, as strikes and protests at fields and export terminals took an increasing toll on the oil sector (see Figure 4). Militia groups formed during the revolution have been central to the more recent problems, as weak central government security forces have been unable to exert control. The extent of the disruption is enormous. In 2011, 411 million barrels of Libyan output were lost due to the revolution. The total annual disruption fell to under 75 million barrels in 2012 as oil fields were rapidly restarted after the revolution, but in 2013 an estimated 249 million barrels were disrupted as a result of the various protests that increased in significance as the year went on. ${ }^{27}$

Violence linked to uprisings has also impacted production elsewhere in the region. Syria has been on an inexorable descent into civil war and bloodshed, as the Assad regime has proved unwilling to release its grip on power. Syria is a relatively minor oil producer, averaging 0.4 million b/d in 2010, but this figure has reportedly fallen below 20 thousand b/d as fighting and international sanctions disrupted the entire oil sector. ${ }^{28}$ As of January 2014, the Syrian government reported total economic losses, as a result of the domestic crisis, of over $\$ 20$ billion, largely due to losses incurred by the country's hydrocarbon sector - both through direct (damage to infrastructure, spillage, and theft) and indirect (ceased oil exports) losses. ${ }^{29}$ Yemen, at around 0.3 million b/d prior to the Arab Spring, is another relatively minor producer. Even before 2011, Yemen was a fragile state, but it has been further destabilized and now sees frequent militant attacks disrupting oil production, particularly due to bombings of the 0.2 million b/d Marib pipeline. Between early 2011 and the end of 2013, 215 million barrels of Syrian and 108 million barrels of Yemeni oil production have been lost (see Figure 5). ${ }^{30}$ 
Figure 4: Libyan oil production, million b/d

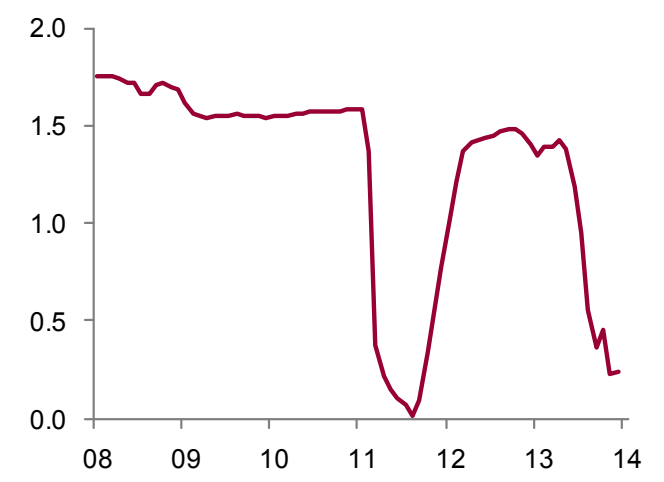

Source: OPEC, MEES
Figure 5: Syria and Yemen oil output, million b/d

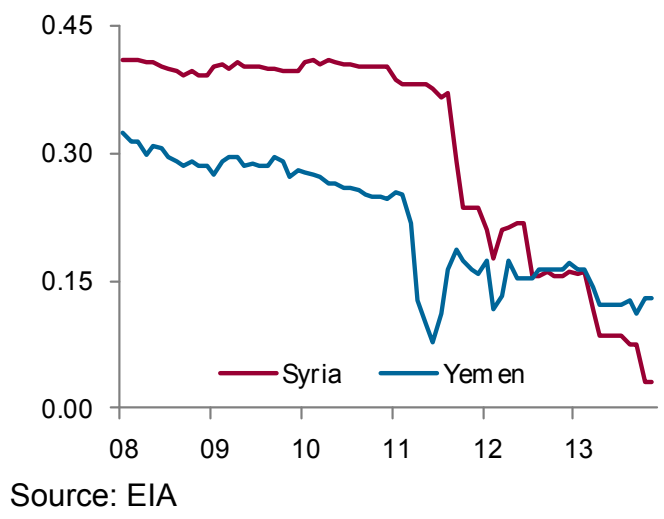

Egypt has seen the impact of the Arab Spring on its energy sector play out in a fundamentally different way. Despite fraught politics, the episodes of serious violence before and after the overthrow of President Hosni Mubarak have not had a direct effect on Egyptian oil and gas output - given that the initial concentration of political protest through youth protest movements occurred in Cairo, while the Egyptian oil and gas fields, which are mainly in the Western Desert and offshore, are relatively isolated. Oil production has held remarkably steady around the 0.72 million b/d level. Egypt's energy sector has primarily been affected through the lack of badly needed investment in the maintenance and expansion of the country's oil and gas production capacity, with natural gas fields and refineries being particularly affected. The lack of investment into new production capacity that dates back to the mid-2000s, but which has been further delayed by near-political paralysis since early 2011 , is likely to fuel Egypt's rapidly growing gap between domestic production and consumption of crude oil and oil products. This gap has curtailed the country's ability to generate much-needed export revenues to fund the process of rebuilding Egypt's post-revolutionary economy and, alongside the loss of tourist revenue and of foreign investment, has left Egypt reliant on the Gulf Cooperation Council countries to supply Egypt's growing domestic energy gap. ${ }^{31}$

Short-term supply disruptions due to the Arab Spring have happened in parallel with supply disruptions in other parts of the MENA region. Despite the absence of a secular youth-led Arab Spring uprising in its own right, Iraq has also been affected by the spill-over from events in other countries during the Arab Spring, particularly by the increasingly sectarian conflict in Syria. Rising sectarian tensions have led to an upsurge in violence in Iraq including bombings of the Kirkuk-Ceyhan export pipeline and attacks on other oil infrastructure in northern Iraq. ${ }^{32}$ Beyond the well-publicized maintenance work at the southern Basra terminal - which began in September 2013 and will continue into spring 2014 - that has slowed the growth of Iraqi oil exports, the ongoing dispute between Baghdad and the Kurdistan Regional Government over exports from Iraqi Kurdistan has limited Iraq's potential in the oil market. ${ }^{33}$ Iran has seen the most dramatic losses, as a result of US sanctions on Iranian crude exports linked to the Iranian nuclear crisis. Since mid-2012, Iranian oil production has dropped by around one million b/d to around 2.7 million b/d and is likely to remain near this level unless a comprehensive deal can be reached between Iran and the P5+1 world powers. ${ }^{34}$

The combined production oil losses from the Arab Spring disruptions (Libya, Syria, and Yemen) and the Iranian sanctions have averaged 1.5 million b/d since the start of 2011. The highest level of disruption to date occurred in September 2013 when, on average, over 2.7 million b/d of production was offline from these four countries. At the end of 2013, the accumulated lost MENA crude production (including Iran) over the previous three years exceeded 1,600 million barrels. The amount 
of oil production lost in recent years is significant even when compared with some other major oil market disruptions (see Figures 6 and 7 and Table 2).

Figure 6: MENA supply disruptions, million b/d

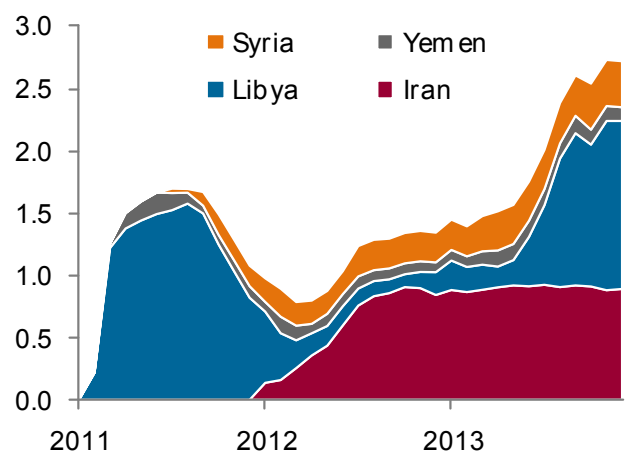

Source: Authors' calculations based on OPEC supply estimates and EIA International Energy Statistics

\section{Figure 7: Lost MENA oil output, million barrels}

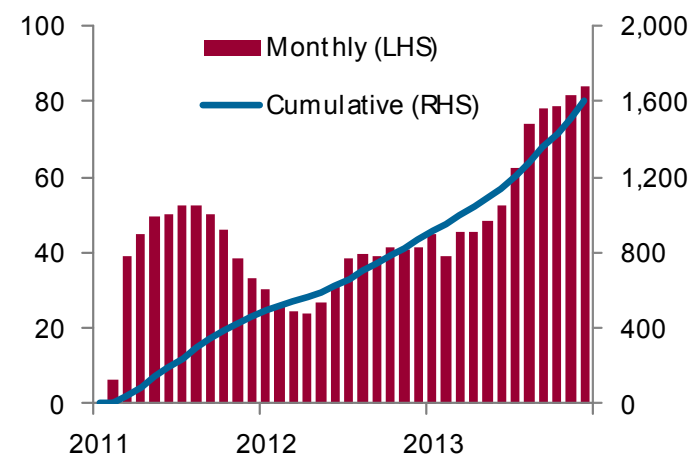

Source: Authors' calculations based on OPEC supply estimates and EIA International Energy Statistics

Table 2: Historic disruptions to oil production

\begin{tabular}{|lccc|}
\hline Event & Dates & Total loss (m b) & Peak supply loss (m b/d) \\
\hline Historic & \multicolumn{3}{c|}{} \\
\hline Iranian revolution & Nov 1978 - Apr 1979 & 678 & 5.3 \\
Iraq Invasion of Kuwait & Aug 1990 - Dec 1991 & 2,488 & 5.35 \\
US Invasion of Iraq & Mar 2003 - Dec 2011 & 1,417 & 2.4 \\
\hline Current & & & \\
\hline Arab Spring (Libya,Yemen \& Syria) - continuing & Jan 2011 - Dec 2013 & 1,058 & 1.85 \\
Iranian sanctions - continuing & Jul 2012 - Dec 2013 & 543 & 0.92 \\
\hline Arab Spring and Iranian Sanctions & & $\mathbf{1 , 6 0 1}$ & $\mathbf{2 . 7 3}$ \\
\hline
\end{tabular}

Source: Authors' calculations based on data from MEES and EIA International Energy Statistics. The loss is estimated as the difference between the maximum level of oil production in the sixmonth period prior to the disruption and the actual supply during the event.

\subsection{Impact on oil prices}

The disruptions in the region have naturally raised significant anxieties in the oil market, and at times have contributed to a rise in the oil price. Parallel production shutdowns outside MENA producers, including significant losses in Nigerian output and shutdowns in South Sudan's (albeit comparably small) oil production, exacerbated market anxieties. ${ }^{35}$ Globally, supply disruptions rose rapidly in early 2011 and exceeded 1.5 million b/d for most of the year, largely due to the revolution in Libya (see Figure 8). In this context, the prospect of a new sanctions round targeting Iranian oil in July 2012, together with Iranian threats of closing the Strait of Hormuz, prompted a round of concerns in late 2011 that oil prices could be driven to extremely high levels. ${ }^{36}$ 

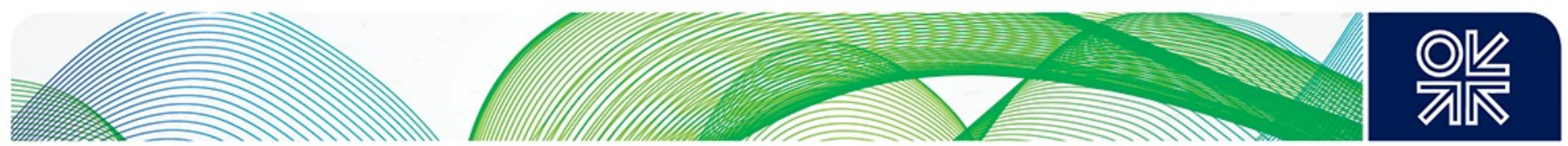

Figure 8: Global supply disruptions by country, million b/d

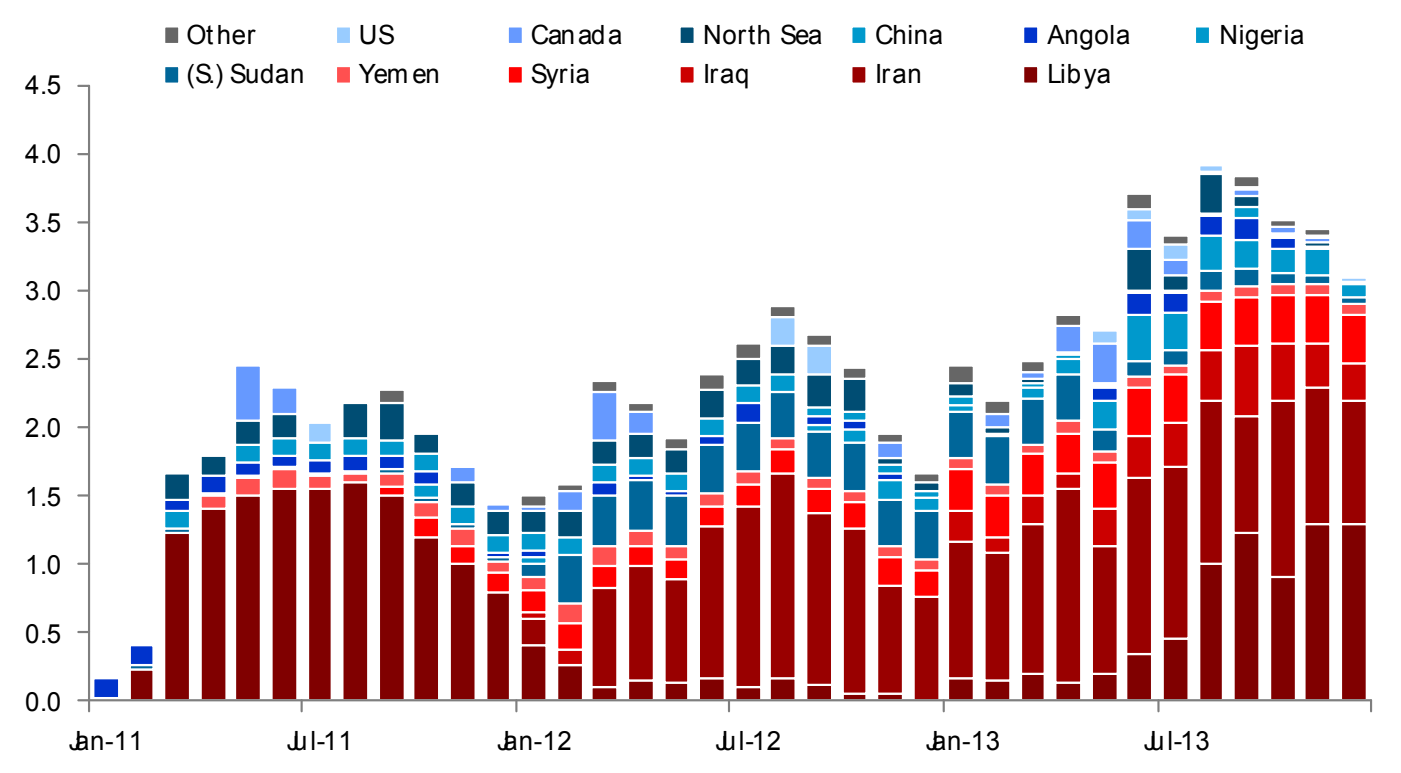

Source: Authors' calculations based on OPEC supply estimates, EIA Petroleum Supply Monthly, EIA International Energy Statistics and various national government statistics

Despite these big supply losses, the actual effect of the Arab Spring and Iranian sanctions on oil prices has fallen far short of alarmist projections. This is in part because the Syrian crisis did not spill over to and further destabilize Iraq to an extent that reduced its oil production significantly; Iran did not make any move to close the Strait of Hormuz; and oil markets have shown remarkable resilience in dealing with those supply disruptions that did materialize, through adjustments in price levels but, more importantly, through adjustments in price differentials that helped oil markets redirect oil flows and encouraged inventories to be drawn down. The Gulf Cooperation Council (GCC) states have, with the partial exception of Bahrain, remained largely unaffected by the Arab Spring, leaving those key producers with spare capacity - primarily Saudi Arabia and to a lesser extent Kuwait and the UAE - as stable and reliable suppliers.

As Figure 9 below shows, between October 2009 and October 2010, the oil price generally oscillated within a narrow band of $\$ 70$ to $\$ 80$ per barrel. In October 2010 , however, the oil price broke loose and moved away from the band. This took place well before the start of the Arab uprisings, and occurred mainly in response to the flow of strong oil demand data. In fact, we would argue that the recovery in oil demand from the deepest worldwide economic recession in decades was the main factor behind the rally in Brent oil prices in 2009 and 2010.

The events of the Arab Spring in early 2011 were indeed the catalyst for prices moving back above $\$ 100$ per barrel from February 2011 onwards, and only once in the last three years has the monthly average price fallen below that level. Yet, geopolitical events have not offered sustained support for oil prices. Events have triggered brief price increases, especially in early 2011 following the start of the Libyan uprising; in early 2012 on fears of a military confrontation between Iran and the USA and anticipation of Iranian oil sanctions; and again in early 2013 over a number of security concerns in North Africa ranging from oil disruptions in Libya (paralleled by French intervention in southern neighbour Mali), to protests in Egypt, and growing concern about security in the aftermath of Algeria's In Amenas attacks. A feared spike in prices to new record highs, however, has not materialized. Instead, the oil price has generally been stuck in a $\$ 100-110$ per barrel range. 
Figure 9: Brent prices and key MENA events, \$ per barrel

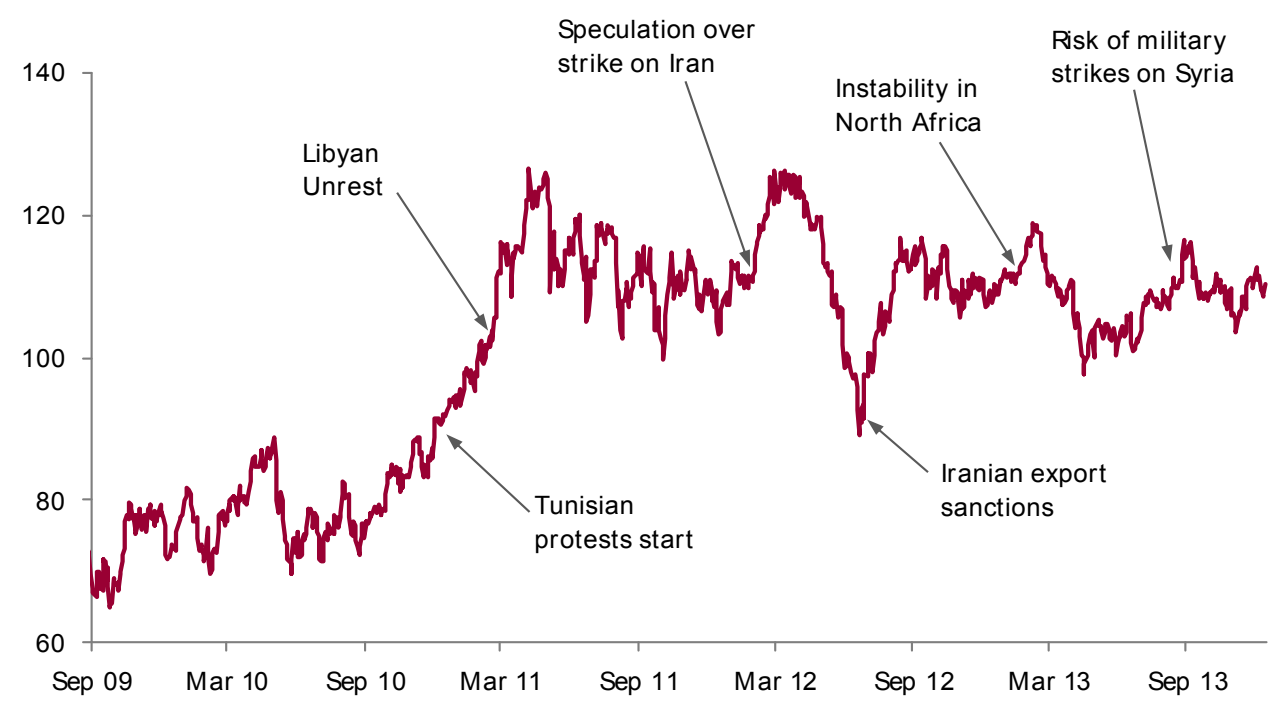

Source: Bloomberg price data, Authors' comments

There are several factors that explain why prices have not risen further despite the significant disruptions to supply experienced over the last three years:

(i) Spare capacity inside OPEC. The availability of sufficient spare oil production capacity, mainly held by Saudi Arabia and to a lesser extent by other Gulf States, is one of the most likely reasons for oil prices remaining within a narrow band. These countries have proactively used their spare capacity to fill the gaps left by Arab Spring disruptions and Iranian sanctions. The combined output of Saudi Arabia, Kuwait, Qatar, and the UAE has risen from around 14 million b/d prior to the start of the Arab Spring to above 16 million b/d for much of the last three years. ${ }^{37}$ This has not just been an increase in absolute terms. Problems affecting other OPEC members have led to the Gulf States' share of total OPEC production rising above 50 per cent since the beginning of the Arab Spring - touching 55 per cent in September 2013. ${ }^{38}$

Figure 10: Saudi Arabia oil output, million b/d Figure 11: Gulf OPEC states output, million b/d

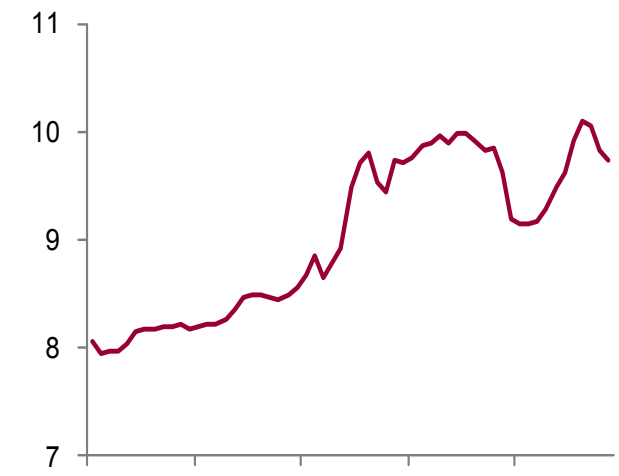

Source: OPEC

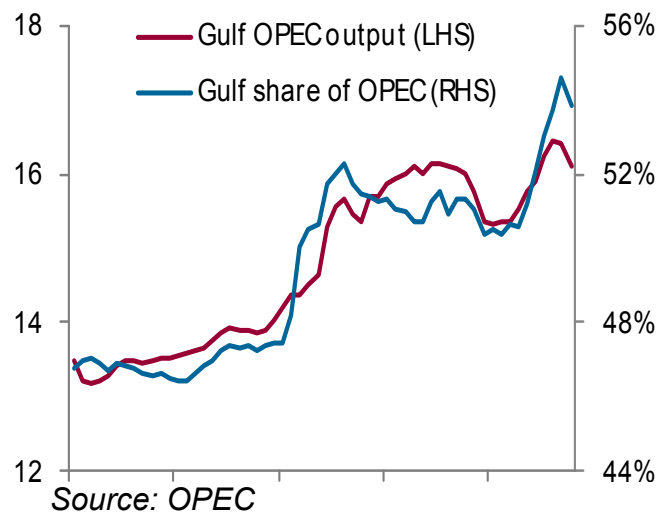

(ii) North American unconventional oil production growth. The last three years have also seen the rapid growth of US tight oil production and this has helped to keep the market well supplied. In 
contrast, non-OPEC supplies outside the USA have generally disappointed. Mature basins such as the North Sea and in Mexico are declining, and potential sources of supply growth such as Brazil and Kazakhstan have been beset by delays and disappointment (see Figures 12 and 13). Nevertheless, US output growth has prompted excessive optimism about the long-term supply outlook and the need for oil supplies from the Middle East. The recent shift in the oil market's fundamental narrative from one of oil scarcity, to one where oil is abundant and it is expected that spare capacity will rise in the coming years, seems to have also mitigated fears over the potential impacts of disruptions.

Figure 12: US output growth, y/y, million b/d

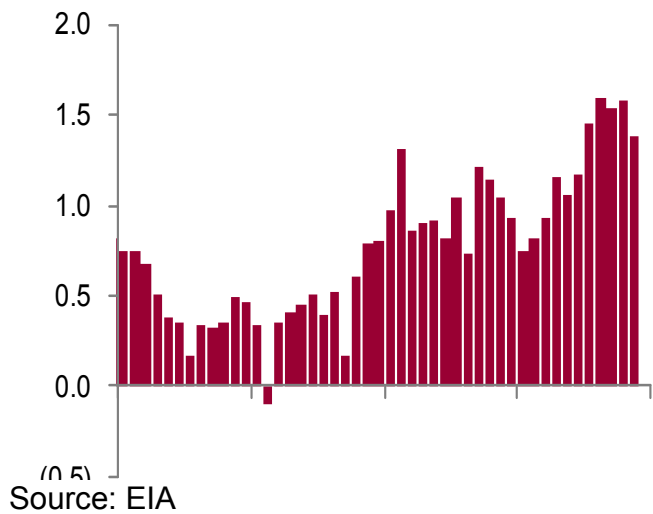

Figure 13: Rest of non-OPEC, y/y, million b/d

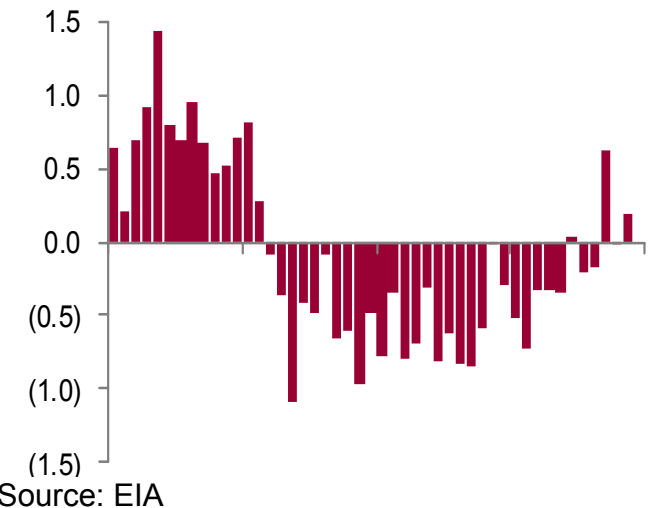

(iii) Limited demand growth. Subdued global oil demand growth due to weak global economic performance has also helped to mitigate the impact of MENA region supply losses. Global oil demand increased by 0.5 million b/d in 2011, then by 0.9 million b/d in 2012, and rose to 1.2 million b/d in $2013 .^{39}$ This growth has prevented the market from becoming oversupplied, but has also not led balances to tighten to the extent that oil prices would be forced to find a higher price range.

It is therefore the combination of strong US tight oil growth, limited demand growth, and increased output from the Gulf States that has helped the oil market weather the supply outages caused by the Arab Spring and Iranian sanctions. However, by the same token, it is these very supply outages, together with the risk premium associated with potential further outages, that have contributed to keeping oil prices elevated above the $\$ 100 /$ barrel mark in recent years.

\subsection{The Arab Spring and regional gas markets}

Recent events have also had an impact on gas production across MENA, although the region's overall limited role as a global gas supplier, and Qatar's stability during the Arab Spring, has meant that the effect has been far lesser on gas than on oil markets. Qatar is the largest LNG exporter in the world and has been insulated from disruptions throughout the Arab Spring. Other producers have experienced a range of direct and indirect effects. Libya, Egypt, Yemen, and Algeria have each seen periods of disruption to their gas exports. Libyan pipeline exports to Italy were offline during the civil war in 2011 - with Greenstream pipeline's closure to Italy in 2011 being the longest disruption to regional trade in pipeline gas so $\mathrm{far}^{40}$ - and have been disrupted by protests in late 2013. However, the impact of the loss of Libyan gas on the Italian and European markets has been minimal and ENI has been able to meet its customers' demand for gas without much difficulty given subdued gas demand and comfortable storage levels. Yemen's gas pipeline to the Bahlaf terminal has been bombed multiple times by insurgents, with the most significant disruption occurring in spring 2012 , before the planned maintenance of the export terminal. ${ }^{41}$ 
Figure 14: Libyan gas exports, bcm per month

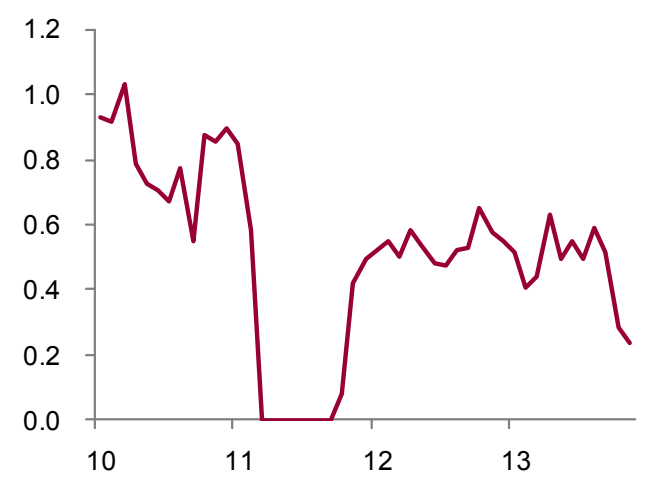

Source: SNAM and Bloomberg data
Figure 15: Yemeni gas exports, bcm per month

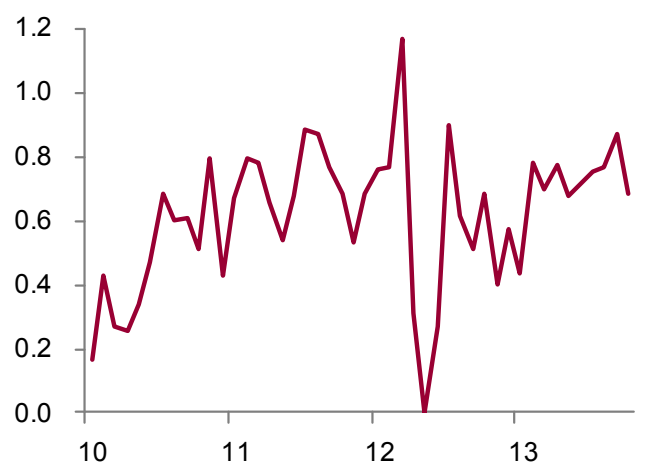

Source: Bloomberg data

Algeria, the MENA region's second largest gas exporter, has, for most of the duration of the Arab Spring, maintained relative stability, despite recurring protests in the capital Algiers. The Algerian government's appearance of having full control over insurgent groups nevertheless came to a sudden halt in January 2013 with a devastating terrorist attack on the country's gas processing facilities in In Amenas. The reduction in gas output from In Amenas (which accounts for around 10 per cent of Algerian gas production) following the attacks has contributed to declines primarily in Algerian pipeline exports in 2013, although weak demand in the key markets of Spain and Italy (down by 8 per cent and 6 per cent from their 2012 levels respectively) and the renegotiations of take-or-pay gas contract provisions between the Algerian government and ENI, have also played their part. ${ }^{42}$ The impact of the In Amenas crisis on European gas prices was short-lived and negligible overall; UK NBP prices, as an indicator of European prices, rose around 4.4 per cent after the initial attack, but dropped back shortly after (see Figures 16 and 17).

Figure 16: Algerian gas exports, bcm/month Figure 17: NBP prices in 2013 pence/therm
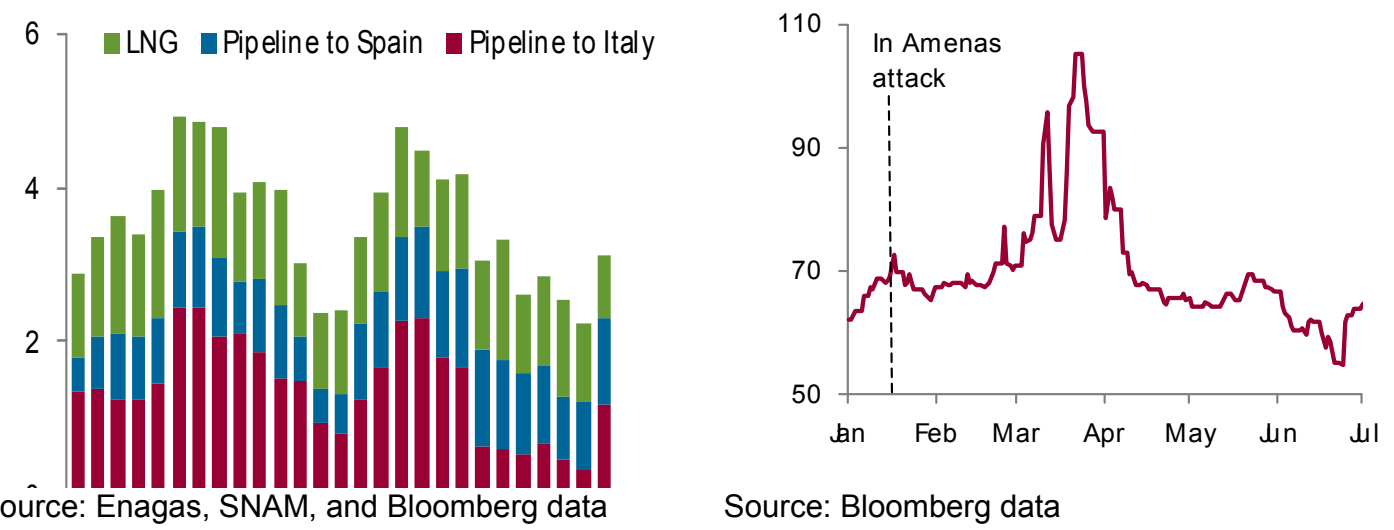

Source: Enagas, SNAM, and Bloomberg data

Source: Bloomberg data

In general, disruptions to North African gas production have had limited impact on global, particularly European, gas markets due to a variety of factors. Inside Europe, which is one of the main markets for North African gas, low post-recession gas demand, together with ample pipeline gas and global LNG supplies, have prevented Libyan and Algerian supply disruptions from causing widespread market concern. Indeed, some have argued that the short-term disruption came at a commercially favourable point in time for ENI, which was struggling to fulfil its take-or-pay commitments for Russian gas in any case. ${ }^{43}$ More generally, outside Qatar and its dominance in the LNG market, MENA gas does not have the same significance as MENA oil. Despite the region's large natural gas reserves, its 
share in global production remains quite small and most of the gas produced is used in domestic markets. Furthermore, with MENA gas consumption growing rapidly over the last 10-15 years, driven largely by demand for electricity, energy-intensive industries, and by artificially low prices, the region (outside Qatar) will continue to play a relatively modest role in international gas exports. ${ }^{44}$ Indeed, many countries in the region have already turned into net gas importers, and the contribution of some of the region's traditional LNG exporters, such as Oman, Egypt, and Algeria, to global LNG trade is expected to decline in the next decade, as domestic demand continues to grow faster than domestic supply and as new global players such as Australia, East Africa, and the USA turn into LNG exporters. 


\section{The Arab Spring's long-term effects on the MENA's energy sectors}

Notwithstanding the fact that oil and gas markets have shown resilience in dealing with the recent acute disruptions originating from MENA, the Arab Spring's more indirect effects, whose full repercussions are expected to be felt over the long term, are likely to make the most lasting mark on oil and gas markets. Most importantly, political turmoil and fear of regional spill-over will alter many regional oil and gas producers' priorities in social spending; this will affect sectoral policies such as the ability of governments to implement large energy infrastructure projects and adjust their fiscal terms to attract foreign investment, in view of the fact that many MENA oil and gas producers have changed their priorities relating to the maximization of oil and gas resource rents. It will also reinforce pre-existing difficulties in reforming the region's domestic energy markets, most importantly energy prices, with likely consequences for medium- and long-term domestic energy demand growth, which will affect some of the MENA oil and gas producers' export capacity. The Arab Spring is also likely to affect foreign companies' investment decisions into the wider region as political instability, the threat of spill-over, and the deteriorating security thereof increase country-based and regional risk ratings and the cost and the uncertainty of investing in the region's energy sector.

\subsection{Increase in social spending}

Many of the MENA region's larger oil and gas producers - principally the Gulf monarchies and, to a lesser extent, North Africa's hydrocarbon producers - have historically overseen large welfare states that have channelled oil and gas revenues into social security, health, education, and the provision of employment as part of these countries' implicit social contracts. Many of these countries, including those unaffected by the immediate repercussions of the Arab Spring, have responded to the upsurge in political turmoil across the region by further increasing their social spending. Across the region, spending is being directed towards areas such as housing, employment creation, unemployment benefits, subsidies, higher wages for government workers, and compensation for rising living expenses. For instance, Saudi Arabia's budget rose from \$127 billion in 2009 to $\$ 219$ billion in 2013, largely because of big increases in social spending and infrastructure projects (see Figure 18 below). In 2014 , the government set its budget spending at a record $\$ 228$ billion. ${ }^{45}$ In Kuwait, government spending jumped by 14 per cent for the fiscal year 2012/13, and again by over 50 per cent for the first half of the fiscal year 2013/2014, much higher than originally expected. ${ }^{46}$ The increase in government spending was driven almost entirely by current rather than capital expenditure, that is benefits, subsidies, and government salaries together with public sector 'job creation'.

In addition to increased spending on their local economies, the oil-rich Gulf States have increased their financial support for some of their ailing strategic partners in the region. For instance, following the protests in Bahrain and Oman, the Gulf Arab foreign ministers pledged $\$ 20$ billion in financial aid over 10 years to the two neighbouring Gulf countries. ${ }^{47}$ The national armies of Saudi Arabia and the UAE were dispatched, and no financial efforts were spared, to assist the Bahraini government in restoring order following its own political protests that escalated into violence in spring $2011 .{ }^{48} \mathrm{Gulf}$ support has also been instrumental in keeping Egypt's severely restrained domestic energy sector from collapsing under several years of neglect and lack of investment. While Egypt's production level for oil has remained mostly stable throughout the Arab Spring, the country's surging domestic demand and large pre-existing export commitments for Egyptian natural gas have meant that the country's energy sector would have been at the onset of virtual collapse by 2013, were it not for a series of Gulf aid packages. Kuwait, Saudi Arabia, and UAE pledged a \$12 billion aid package to Egypt following President Morsi's overthrow by the military, in addition to in-kind aid and loans in the form of Qatari and Emirati LNG swaps and fuel supplies from the UAE, Kuwait, and Saudi Arabia. ${ }^{49}$

To fund their increasing expenditure outlays, oil exporters have become even more dependent on high oil revenues, forcing them to assume higher oil prices in order to balance their budgets. Indeed, 
the oil price assumed by MENA oil exporters in their official budgets has risen sharply in recent years, from a reported range of \$40-55 per barrel in 2008 to above $\$ 70$ per barrel in 2014 for Kuwait, and $\$ 100$ per barrel for Iran (see Figure 19). ${ }^{50}$ Research by APICORP suggests that effective break-even prices, which factor in the cost of production on a full life-cycle basis, are significantly higher, with estimates of the OPEC output-weighted average having risen to $\$ 105$ per barrel in $2013 .{ }^{51}$ Many analysts, therefore, expect oil producers to be more assertive in their output policies, to defend prices should oil prices fall to levels deemed unacceptable. However, it could be overly simplistic to treat a calculated break-even price as indicative of the new price floor for the world's major producers. Key Gulf oil producers such as Saudi Arabia, Kuwait, and the UAE have low foreign and domestic debt, as well as large reserves of foreign currency, which provides a large fiscal buffer - meaning that they are in a better position to deal with lower oil revenues for a short period. Also, producers do not have to balance their budget on an annual basis. However, the increase in social spending puts pressure on governments to maximize the rent captured from oil exports by supporting prices.

While the increased break-even price implies greater dependency on high oil prices, a potential fall in the oil price could induce some of the producers to increase output to compensate for lower revenues. Under certain conditions, this could be self-defeating if the overall increase in supply leads to a sharp fall in oil prices and a decline in oil revenues. Nevertheless, the pressure to increase social spending can induce some producers to release more oil to the market rather than to restrict output depending on market conditions, the strategic responses by key producers, and the degree of cohesion within OPEC.

Figure 18: Saudi Arabia public expend., \$ billion

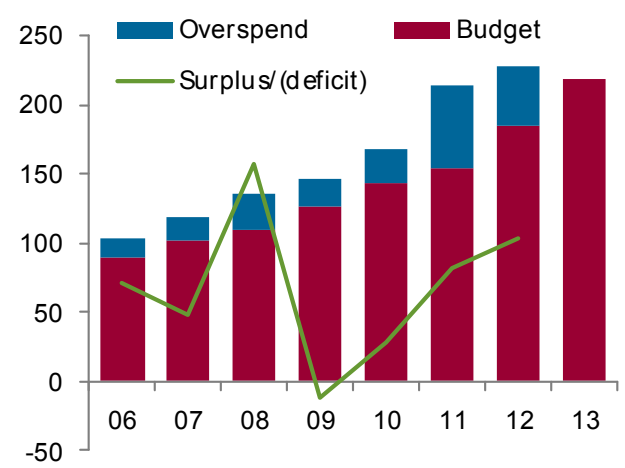

Source: Kingdom of Saudi Arabia Ministry of Finance

\section{Figure 19: Oil price in budgets, \$ per barrel}

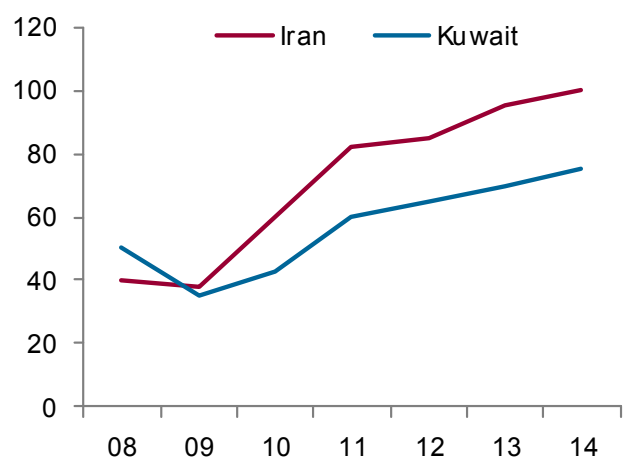

Source: Media reports of Iran and Kuwaiti government budgets

\section{Effects on regional depletion policies}

There has been a general view in some key producing countries, especially in the resource-rich countries of the GCC, that oil reserves should be left underground for future generations. ${ }^{52}$ Such a view implies a more conservative depletion policy and hence a more conservative approach to increasing investment in upstream. In countries where the new political order is still taking shape in the aftermath of the Arab Spring, increased pressures on social spending, or the belief among new political elites that they may not remain in power for long, may induce governments to attach less weight to future generations and more weight to short-term political stability and staying in power, leading them to increase investment in projects with short time-spans to try and maximize current production. ${ }^{53}$ While this might deliver higher output in the short term, it would probably come at the 
expense of reservoir damage, particularly if it follows previous disruptions and unplanned shut-ins caused by political instability. Libya may offer an example of this, with its rapid ramping up of output in late 2011 and early 2012, often using temporary repairs.

\subsection{Delay of energy pricing reform}

Energy subsidies are one of the most contentious forms of government spending, not only in the Middle East but across many oil and gas producers and emerging economies. In most MENA economies, liquid fuel and natural gas are sold on domestic markets at prices significantly below their international market value (implicit government transfers, or subsidies), or below the cost of import in the case of energy imports (via explicit subsidies), with the result that regional energy prices have, for many decades, been among the lowest in the world (see Figure 20). ${ }^{54}$ Subsidies are an indirect form of social spending and, in the case of explicit subsidies, have made a major contribution to the rapid rise in government expenditure witnessed in many countries across the region. For example, fuel subsidies are budgeted by the Egyptian government at around $\$ 14.3$ billion for the fiscal year of 2013/2014, about a sixth of total governmental expenditure and more than the equivalent of total Gulf aid pledged to Egypt for the running fiscal year. ${ }^{55}$

The generally low energy pricing in many MENA economies, and the various unintended consequences of energy subsidies, are visible throughout the region. Energy subsidies distort market signals and lead to an inefficient allocation of resources. They encourage wasteful consumption and disincentivize investment in energy efficiency. Energy subsidies are key contributing factors to many of the region's consumption patterns, which include fast growth in consumption of various fuels and electricity, high-energy intensity, and the reliance on energy-intensive industry. Where energy subsidies are poorly implemented and do not allow producers to recover the full cost of production, they may also deter necessary investment in the energy sector, and hence exacerbate existing or expected capacity shortcomings. ${ }^{56}$ Thus, a low pricing environment has the effect of increasing the gap between supply and demand over time, by contributing to rapid domestic energy consumption while reducing the incentive to invest in new productive capacity.

Because subsidies continue to be a popular form of government spending, the Arab Spring is likely to reinforce governments' reluctance across the MENA to reform domestic energy prices in the immediate future. Past cases of delayed reform as a direct result of the Arab Spring are those of Egypt, which had government plans to reform energy subsidies prior to the ousting of the Mubarak-led government in 2011, and Bahrain, whose domestic fuel price reform plans were quickly dropped from the government's agenda following the outbreak of popular unrest in February $2011 .^{57}$

Social pressure is likely to continue to at least delay such reforms, in order to fend off social unrest. All else being equal, this is likely to result in continued solid growth of energy consumption in these countries. For instance, in Egypt, political turbulence has stalled the reform of energy subsidies and exacerbated delayed payments to foreign gas companies. This has resulted in rapidly rising demand and delays to new supply projects, forcing the government to divert gas intended for export clients to meet domestic demand. In the summer of 2013 Egypt relied on help from Qatar, which donated five LNG cargoes that were used to meet Egypt's contractual supply commitments, to maintain this unsustainable balancing act. ${ }^{58}$ Egypt is only a particularly acute case of a wider regional problem. Despite the region's massive reserves, rapidly rising demand for natural gas is absorbing almost all of the increases in production over the last ten years. 
Figure 20: 2012 Retail prices in selected MENA and non-MENA countries, US\$ per litre

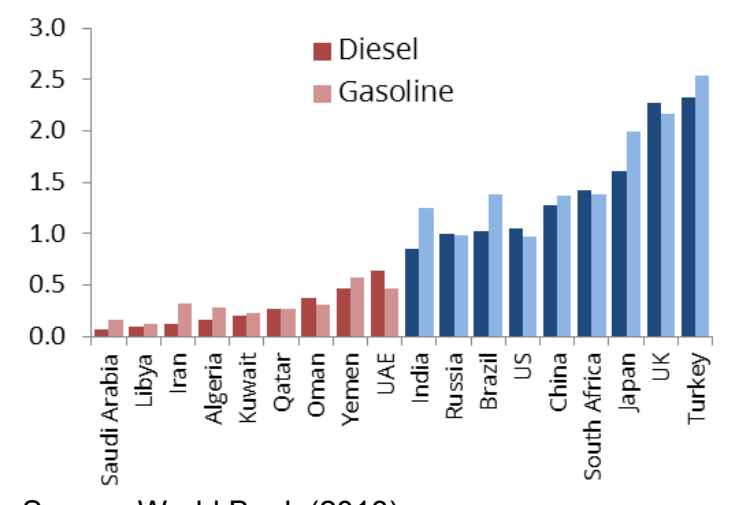

Source: World Bank (2013)
Figure 21: ME gas supply and demand, bcm/year

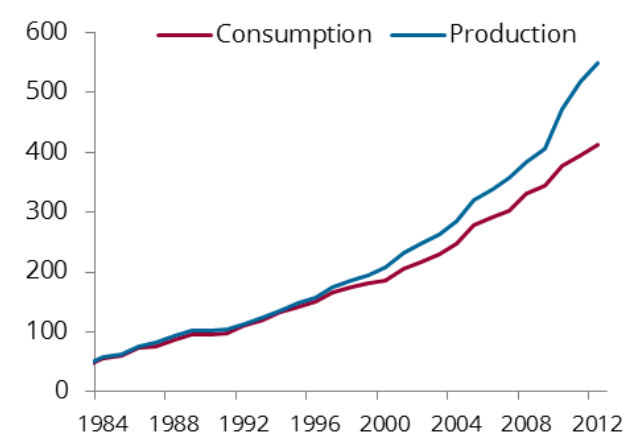

Source: BP (2013)

Furthermore, many MENA governments will anxiously focus on creating jobs for young people, in the hope of allaying their socio-economic grievances. In gas-rich countries, these efforts will take the form of investment in energy-intensive industries using gas as feedstock. Policymakers in the region have invariably considered the availability of relatively cheap gas feedstock as a source of competitive advantage for their economies, allowing them to attract foreign investment, add value to their resources, and create job opportunities for unemployed young people. Although many experts are sceptical about the viability of this strategy, the recent uprisings will only reinforce this approach. As a result, instead of pushing for export polices, some MENA governments will increasingly want to use gas domestically to create jobs and improve living conditions. This could lead to smaller volumes of gas being available for export than would otherwise have been the case, and may further reinforce the importance of contractual terms, such as those for local content, inside their domestic oil and gas industries.

\subsection{Upstream investment and long-term productive capacity}

The Arab Spring uprisings will also have direct implications on the region's investment environment, on the participation of foreign players in the energy sector, and hence on the long-term productive and export capacity of the region. Although many MENA countries have large resource endowments, transforming these endowments into revenue requires high levels of investment and long-term strategic planning, including the attraction of foreign investment and technology into the sector. While MENA countries have grappled with a variety of investment barriers for years, the Arab Spring has clearly reinforced some of the barriers which hold the potential to further affect spending and investment priorities across different MENA oil and gas producers; this includes those MENA producers that have remained unaffected by direct political protest. Most of these priorities are likely to influence decisions whether existing petroleum laws and fiscal regimes provide the necessary incentive for foreign investment into the upstream sector.

\section{Security}

Violence and security problems have affected oil and gas production in a number of MENA countries. The risk that poor security undermines long-term investment rates in new upstream capacity is not so much because oil and gas companies are unwilling or unable to operate in dangerous environments, as operations in countries such as Iraq and Nigeria show. However, security concerns introduce additional costs and risks that reduce the attractiveness of investment opportunities, particularly where existing fiscal terms offered to investors are already poor. Security risks across North Africa 
have fundamentally increased over the last three years. The highest profile incident was the January 2013 attack on Algeria's In Amenas gas plant, which threw the country's reputation for secure oil and gas operations into question. ${ }^{59}$ Perhaps Libya faces the most serious situation, as the government is unable to maintain security at oil and gas facilities; this has led to many international companies suspending plans to resume exploration, or even considering abandoning operations in Libya. ${ }^{60}$

In Iraq, more than ten years after the removal of the Saddam regime by US forces, a persistently difficult security environment necessitates costly security arrangements. As a consequence of the intense violence of the decade since the 2003 US invasion, Iraq's energy sector has developed a high level of security, particularly in the protection of foreign workers. However, recent pipeline bombings and the killing of foreign contractors in mid-December 2013 show the sector is not entirely immune to the rising tide of violence ${ }^{61}$ Security challenges are most serious for projects in the centre and north of Iraq. The Angolan firm Sonangol has decided to exit Iraq after several attacks on its fields in the northern Nineveh province. ${ }^{62}$ In Yemen, too, militant activity remains a major problem, one that moved back into public view at the height of the Arab Spring. ${ }^{63}$ Al-Qaeda splinter groups are believed to have sought refuge in both Yemen and Saharan Africa, adding international terrorism to the list of possible threats to emanate from the region.

If levels of violence and political instability in MENA remain high and the disruptions to regional oil and gas production continue, this will also increasingly colour how companies perceive individual countries, and the region as a whole. Far from improving in the wake of the Arab Spring uprisings, security appears to be worsening in many countries across the MENA. The overthrow of long-serving regimes has resulted in power struggles that in many cases are violent in nature. Militant Islamist groups have also become more active across the region because many of the state security institutions that had previously sought to suppress them have been swept aside. It can often be a slow process to establish new military and police forces to counter these numerous security challenges, as we are seeing in Libya, Yemen, and elsewhere in the region. Foreign companies rely on state forces for the security of oil and gas facilities, in addition to their own security arrangements. When government forces are not up to the task, the consequences can be tragic. For these reasons the current lack of security has become a major impediment to upstream investment.

\section{Political instability and policy uncertainty}

Political uncertainty weighs on investment decisions, with repercussions for a country's oil and gas production lasting far beyond the actual time period of political turmoil. Given the large financial commitments and long timelines for upstream projects, political stability is important to companies that want to secure benefits from their investments. At one level, political transitions make bureaucratic delays almost inevitable, especially in a region where stable governments seldom move quickly. A more serious issue is whether political upheavals jeopardize entire projects. This sort of environment tends to reinforce companies' desire for shorter-term projects with faster payback times that are often in conflict with resource holders' visions for their own development. Political instability in several countries in a region can also impact perceptions about the level of political risk, and overall investment attractiveness, of the wider region itself, as recent APICORP research has shown in relation to the Arab Spring ${ }^{64}$ Hence, even where physical security is less of a concern, the political turbulence caused by the Arab Spring has directly impacted the MENA investment outlook.

Historical experience shows that political instability following major political transitions can affect the long-term productive capacity of a country, reducing its future supply potential. The Iranian and Libyan revolution and the Venezuelan unrest, and the lack of security that followed each of these episodes prevented these countries from undertaking the necessary investment in their oil sectors for many years (see Figure 22) ${ }^{65}$ Indeed, in contrast to physical damage to infrastructure, which can be repaired, political instability (due mainly to a lack of political consensus and weak institutional 
framework) reduces the effectiveness of government in a number of areas: implementing its policies; making changes to the regulatory framework, which affects the organization of the oil sector and government's relations with foreign companies; and in transforming attitudes relating to foreign involvement in the oil sector. Several years of political turmoil, transitional governance, severe disruptions to physical investment, and the revision of investment terms will undoubtedly affect MENA producers over the longer term, even as stability may eventually be restored. North Africa, which alongside Syria has been hit hardest, and most directly by the Arab Spring's sweeping political change, is at the forefront of the current concerns. While Libya was able to return to close to its predisruption levels of output fairly quickly, to the surprise of most market analysts, the fragile political context and lack of credible institutions have prevented the country from maintaining or exceeding these levels (see Figure 22).

\section{Figure 22: Pace of production recovery after major disruption, million b/d}

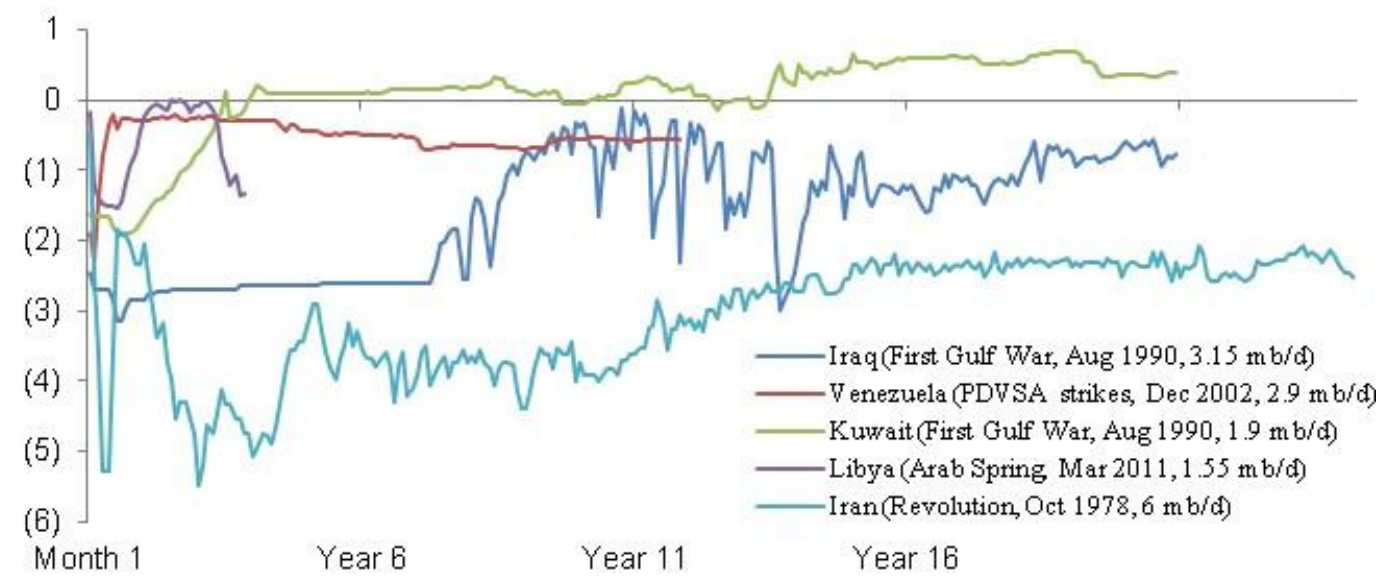

Source: Author's analysis based on OPEC supply estimates

The succession of unstable governments in Egypt since 2011 have caused similar headaches for international companies operating in Egypt's oil and gas sector, in terms of both whether the payment terms of existing concessions are honoured, and in the award of new concessions - some licences were indicatively awarded in 2009 and 2010 but were held up until 2013 because no parliament had been able to approve them. ${ }^{66}$ Payment delays, uncertainty over fiscal terms, and delays in consultation processes have already led to the deterioration of Egypt's domestic energy supply situation. ${ }^{67}$ There are signs that the current military-backed Egyptian government is trying to address these delays and tackle the issues of overdue payments to foreign companies. However, the elections promised for later this year are likely to again be contentious and so the political outlook for Egypt remains uncertain. Relatedly, the sweeping political success of Islamist political parties in countries such as Egypt and Tunisia, and of clearly religiously positioned government figures inside Libya's new government, holds additional reason for uncertainty; for it is not yet clear what policy orientation these entirely new political streams will hold vis-à-vis investment codes and foreign company participation in their national energy sectors over the coming years. ${ }^{68}$ Syria's hydrocarbon sector, too, is likely to remain affected by the current political crisis for the foreseeable future, as a result of international sanctions, the virtual shut-down in domestic oil production, and the exit of foreign oil and gas companies from the country. ${ }^{69}$ 
Paralleling the Arab Spring-induced political uncertainties, two other large MENA oil (and in the Iranian case, gas) producers have suffered from political and investment uncertainty, Iran and Iraq. The Iraqi case has shown that even after stabilizing the security situation to some extent from 2008 to this year, factors such as bureaucratic hurdles, lack of government cohesion, and weak government capacity have all made it difficult to implement the infrastructure projects needed to expand oil productive capacity at a rapid pace, and actual production has consistently lagged projections. ${ }^{70}$ Western sanctions against Iran, Libya, Iraq, and Sudan also limited the access these countries had to technology and foreign capital, hindering their plans for capacity expansion. This remains the situation in Iran, where the role of western companies in upstream projects has been restricted for several decades and almost non-existent in recent years. Sanctions have two effects on oil supplies. First, they usually result in supply losses because they impact the ability of the embargoed country to produce and export oil. Second, they affect the long-term productive capacity by hindering foreign investment and technology transfer, slowing efforts to restore production capacity to pre-disruption levels.

In Libya, the deteriorating security situation, together with the weak business and institutional environment, have slowed exploration activity and hindered foreign investment in the oil sector. In 2005, the IEA had projected that Libya would increase its production to almost 3 million b/d by 2030 . Today these projections seem unachievable given the current context, and the IEA's own 2013 World Energy Outlook reduced its forecasts, now projecting Libyan output will only reach 1.8 million b/d by 2030. Figure 23 shows how far Libyan production has fallen short of that earlier IEA forecast in recent years. A similar, if less dramatic pattern can be seen in Kuwait, which has experienced several years of political deadlock as a result of the emirate's complicated relations between parliament and the ruling family. ${ }^{71}$ As a result of several successive parliaments being dissolved over the past years, the oil minister has changed many times; this has left Kuwait struggling to develop and then implement a long-term strategy to increase production, and to approve projects to achieve growth. ${ }^{72}$ The impact of these issues is only likely to increase in the coming years, as actual production diverges from both the trajectory that the IEA forecast in 2005 and the government's own target of 4 million b/d by 2020 (Figure 24). ${ }^{73}$

Figure 23: Libya output vs IEA '05, million b/d Figure 24: Kuwait output vs IEA '05,
million b/d

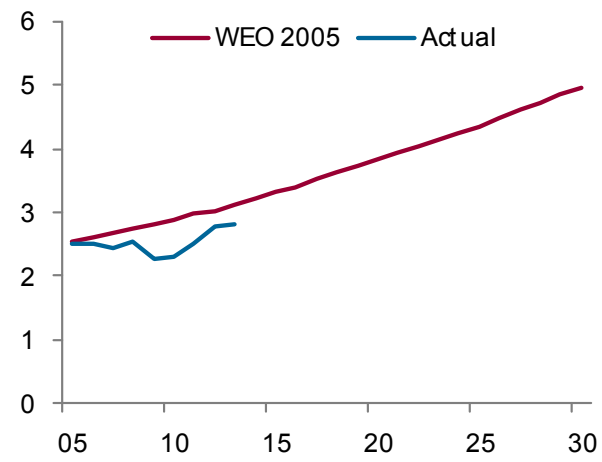

Source: IEA (2005) and OPEC supply estimates

Source: IEA (2005) and OPEC supply estimates

The IEA forecasts global oil supplies to increase by 11.1 million b/d between 2012 and 2035; MENA countries, primarily Iraq, are expected to account for 6.6 million b/d of this increase, taking the region's share of total oil supply from 36 per cent to 39 per cent (see Figures 25 and 26).$^{74}$ One of the biggest concerns is that if investment is not undertaken, global oil supply may suddenly fall short of 
demand, with the effect that the oil price has to increase to high levels to ration oil demand and/or unlock new supplies. While high prices generate high revenues for producers in the short term, they eventually create problems, as high and volatile oil prices may slowdown global economic growth, thereby reducing oil demand. In the longer term, high prices can also cause demand destruction - a particular concern being that high and volatile prices will accelerate oil substitution policies driven by energy security concerns and the climate change agenda. Thus major MENA exporters must arguably consider the global market for their output, not just whether they have the potential domestically to increase production. This requires a stable government and a long-term strategic view.

Figure 25: Forecast MENA oil output, million b/d

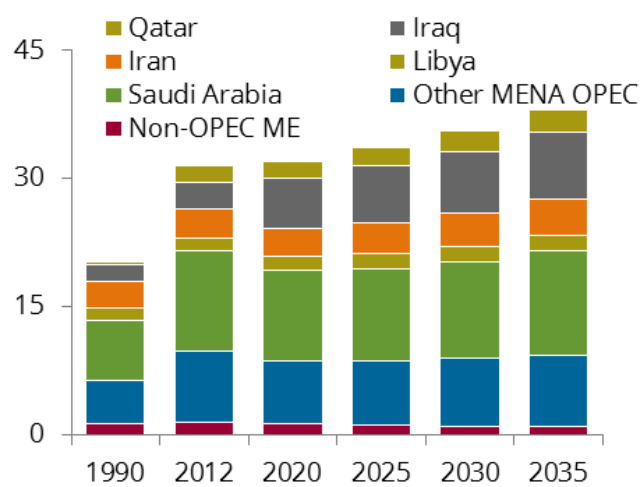

Source: IEA (2013)
Figure 26: Oil output addns. by 2035, million b/d

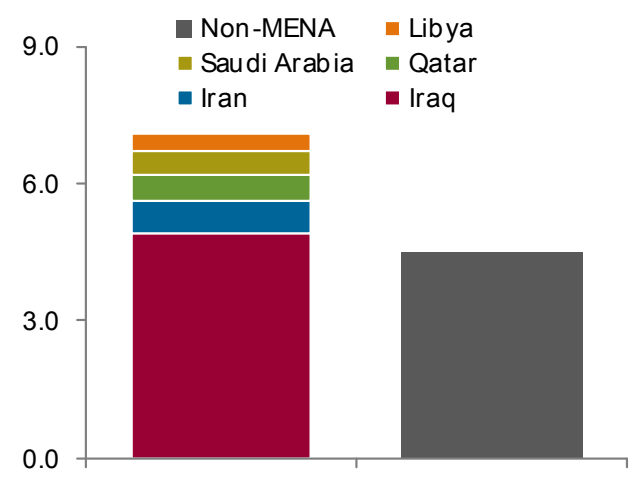

Source: IEA (2013)

\section{Issues of revenue distribution}

It would be difficult enough if MENA governments only needed to develop upstream investment strategies, but this must find its place among a wide range of tasks - particularly challenging in the wake of the events of recent years. A particularly contentious issue in many countries has been the allocation and distribution of oil and gas revenues. In Iraq, disputes between the central government and the Kurdistan Regional Government (KRG) over the distribution of oil revenues, and over which authority has the ultimate power to sign oil contracts with foreign energy firms, have had a profound impact on investment, the nature of the players involved in the various parts of the country, and potential export routes. In Libya, demands relating to the distribution of oil revenues are central to the current disruptions, particularly in the east of the country. The protestors controlling the major ports in the east justify their claims by highlighting the fact that two-thirds of oil reserves and production are in the eastern region and thus revenue sharing along with a more regional political settlement should be written into the new Libyan constitution. ${ }^{75}$

\section{Social spending and fiscal terms}

With governments across the region expanding their medium- to long-term public expenditure through increased public sector wages and social transfers, in the hope that this will quell popular agitation, it is likely that they will seek greater revenues from the oil and gas sector in order to meet these commitments. It is worth briefly recalling the driving forces behind the Arab Spring. Although each country had its own dynamics, the uprisings were generally youth-led and mostly secular. Many of the triggers were economic, from high levels of youth unemployment and rising living costs to perceived economic mismanagement, including widespread corruption among the ruling elite. ${ }^{76}$ Some argue that in Yemen, capital-intensive investments in the oil and gas sector that yielded few local jobs and 
mainly seemed to benefit a small elite, were key contributors to the crisis of political legitimacy that led to the 2011 popular uprising. ${ }^{77} \mathrm{~A}$ similar pattern can be seen in many other oil- and gas-rich MENA countries.

One theme already manifesting itself is a questioning of the fiscal terms that should be offered in oil and gas licensing rounds. International companies are lobbying for more competitive terms, arguing that the costs of exploration and production have risen, particularly given the additional security costs. There is also more caution among the new political elites that are now well aware of the power of the public. The spectre of resource nationalism, as it has been known in the region during the 1960s and 1970s, will of course take a decisively different character today. Rather than leading to calls for the nationalization of their domestic oil and gas industries (much of which has been achieved in previous decades) this drive to maximize the rent in order to increase its distribution, together with closer public scrutiny of signed deals, could reduce the ability of governments to offer more fiscal incentives for foreign investors, thus potentially limiting their involvement in upstream development.

\section{The overall business environment}

In addition to access to the upstream resources, production capacity depends on whether countries offer an attractive general business environment. One of the direct impacts of the Arab Spring has been a deterioration of the general business environment in many of the countries involved. The ousted authoritarian regimes were widely seen as presiding over corruption and excessive state bureaucracies, but what was less well-recognized was the extent of the institutional weakness beneath the security apparatus. Thus, any hopes that the Arab Spring uprisings would quickly yield economic liberalization and an improved business environment, have so far proven false. A 2013/14 APICORP Delphi survey assesses the extent of an 'enabling environment for business' as underpinned by oil, gas, and energy policies and the domestic financial environment. ${ }^{78}$ The survey concludes that energy-relevant business factors were widely perceived to have worsened significantly over the past year in Syria, Sudan, Libya, and Yemen; whereas greatly enhanced business frameworks were found in the UAE, Saudi Arabia, and Qatar, with generally more positive results for the GCC countries than anywhere else in the region (Figure 27).

Figure 27: APICORP's Enabling Environment Delphi Survey Results

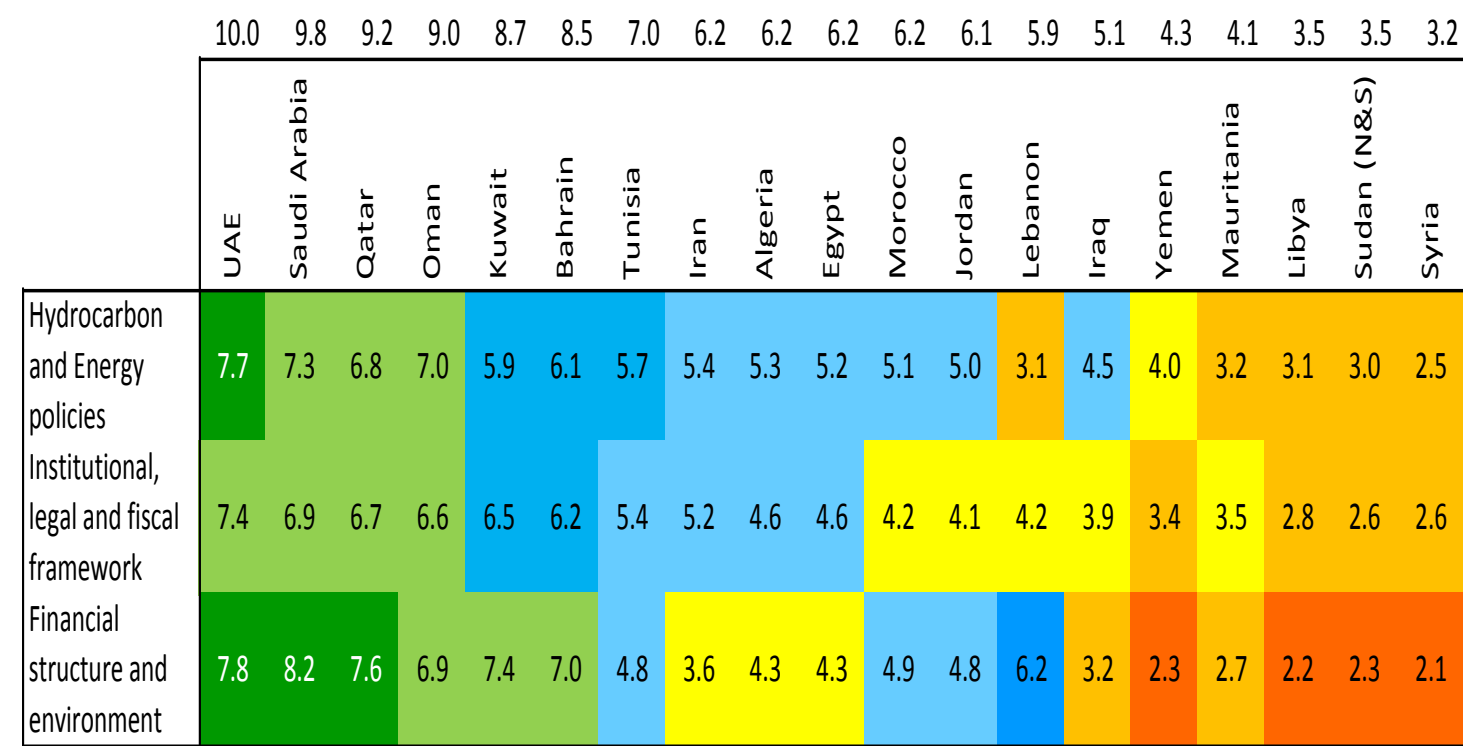

Source: APICORP Research, assessed through a Delphi survey in December 2013. 


\section{Conclusions}

The Arab Spring uprisings may eventually deliver substantial improvements for people across the region and for the investment climate, but these outcomes seem unlikely to be achieved quickly. Meanwhile, the effects of what is now three years of political turmoil, transitional governance, and, in the case of those Gulf oil and gas producers that have remained largely unaffected by the turmoil, fear of cross-regional contagion have begun to leave their mark on the region's energy sectors. The impact of the uprisings has been most visibly and immediately felt in countries directly affected by the Arab Spring - Libya and Syria - where political protests have resulted in the region's fiercest domestic infighting so far and the effect on domestic oil and gas production has been the most drastic. In addition, the energy industries in these countries have largely fallen victim to different interest groups and are likely to remain unstable sources of supply for international markets for the foreseeable future. International sanctions targeting Iranian oil exports have, furthermore, contributed to some of the largest total losses in oil supplies from the MENA region.

The Arab Spring has, however, affected a far larger number of regional energy producers, both directly and indirectly. Persistent attacks on energy-related infrastructure, including production platforms and export pipelines, have repeatedly shut down production and supplies on the Sinai Peninsula, in Northern Iraq and in Yemen. Algeria, too, has been shown to be no longer immune to terrorist attacks against oil and gas producing infrastructure. While these outages are unlikely to result in large losses of oil and gas output for a long period of time, they are a menace to the markets, increasing uncertainty and volatility, and giving rise to adjustment costs for refineries as they seek to replace lost output. The combined effects of continued political instability across several MENA oil and gas producers may hence continue to affect price levels as well as the price volatility of oil for the foreseeable future.

The impact of political turmoil on natural gas exports has been considerably less immediate than has been the case for oil, owing primarily to the region's limited export capacity - beyond the key exporters Qatar, Algeria, Libya, and Egypt. It does, however, illustrate the likely more persistent effects of the Arab Spring and Iranian sanctions on the region's long-term supply potential for both oil and gas, through delays in investment and domestic energy pricing and fiscal reform, even in some of those oil and gas producers that have so far remained mostly unaffected by political turmoil. Egypt's position as a rapidly declining exporter of natural gas, overwhelmed by both fast-rising domestic demand and the combined effects of political turmoil on upstream investment and regulatory reform, serves as an important case in point. Other governments are struggling to make it from one month to the next between economic crises, security problems, and popular unrest. This is hardly the best context for making long-term decisions.

The outlook for foreign investment has also been impacted by recent geopolitical events, as the security environment across much of the region has worsened while the business environment is yet to improve. We are not yet seeing a stampede for the exits, and many IOCs remain firmly committed to their existing upstream projects. However, increasing numbers of foreign companies are scaling back investment, while interest in new MENA licensing rounds is tending to be at best lukewarm. ${ }^{79}$ These rather subtle, yet important, ramifications of regional turmoil in the MENA region are likely to be of much further-reaching consequence for the region's position as a global energy supplier, through their effect on the MENA region's future production and export capacity expansion. However, these kind of long-term effects of the Arab Spring are fundamentally different from the spectre of a regional war suddenly depriving the world of all oil produced in the Middle East'. ${ }^{80}$

An important, partly overlooked, element of the story of the Arab Spring and its impact on oil and gas markets has, moreover, been the remarkable stabilizing role of key MENA producers themselves the most important being Saudi Arabia with its large spare capacity and its ability to compensate for at 
least part of the losses from other regional producers virtually as and when substantial supply disruptions occur. Politically stable Qatar, too, has seen its LNG exports unaffected by the Arab Spring and, accounting for a large share in total MENA gas exports, it has withstood predictions of a general disturbance of regional gas supplies to international markets. The MENA region still holds significant potential to increase oil and gas supplies and exports, particularly if Iraq reaches its full potential and if international sanctions are lifted allowing Iran to fully re-enter the global market. Whether Arab Spring-related political events will eventually curb long-term oil and gas supply prospects in the region hence remains an important question for the next few years. 
${ }^{1}$ In this paper, we include in the MENA region the following countries: Algeria, Bahrain, Egypt, Iran, Iraq, Jordan, Kuwait, Lebanon, Libya, Morocco, Oman, Palestine (where data is available), Qatar, Saudi Arabia, Syria, Tunisia, United Arab Emirates (UAE), and Yemen. Individual data aggregates may differ from this as individually declared.

${ }^{2}$ For a selection of the very wide literature on the political and economic repercussions of the Arab Spring, see Andersen, L. (2011), 'Demystifying the Arab Spring. Parsing the Differences between Tunisia, Egypt and Libya', Foreign Affairs 90, February 2011, 2-7; Joffe, G. (2011), 'The Arab Spring in North Africa: Origins and Prospects', The Journal of North African Studies 16:4, 507-32; El-Katiri, M. (2013), 'The Future of the Arab Gulf Monarchies in the Age of Uncertainties', Strategic Studies Institute and US Army War College, June 2013; Gause III, F.G. (2013), 'Kings for All Seasons: How the Middle East's Monarchies Survived the Arab Spring', Brookings Doha Center Analysis Paper, Doha: The Brookings Institution; Achcar, G. (2013), The People Want - A Radical Exploration of the Arab Uprising, London: Saqi Books; Gerges, F. (2013, ed.), The New Middle East: Protest and Revolution in the Arab World, Cambridge: Cambridge University Press.

${ }^{3}$ For an overview and a discussion of the periodically recurring debate, see Mabro, R. 'On the security of oil supplies, oil weapons, oil nationalism and all that', OPEC Energy Review, March 2008; Chapman, D., Khanna, N. 'The Persian Gulf, Global Oil Resources, and International Security', Contemporary Economic Policy, 24:4, October 2006, 507-19; Chapman, Duane (2009), 'Gulf Oil and international Security: Can the world's only superpower keep the oil flowing?', in Daniel Moran and James Russell, Energy Security and Global Politics: The militarisation of resource management, London, New York: Routledge; Pollack, K. 'Securing the Gulf'. Foreign Affairs, July/August 2003. ${ }^{4}$ The IEA, for instance, recently dedicated part of one of its journal issues to the implications of the Arab spring on global energy markets. IEA (2012), 'Energy', The Journal of the International Energy Agency, Issue 3, August 2012, available online at www.iea.org/media/ieajournal/Issue3 WEB.pdf (retrieved January 2014); Smith, G., 'IEA says MidEast disruptions pose risk to oil market', Bloomberg, 14 November 2013. See also Darbouche, H. and Fattouh, B. (2011), 'The Implications of the Arab Uprisings for Oil and Gas Markets', OIES Working Paper MEP2, Oxford: Oxford Institute for Energy Studies, available at www.oxfordenergy.org/2011/09/the-implications-of-the-arab-uprisingsfor-oil-and-gas-markets/ (retrieved January 2014); Stevens, P. (2012), 'The Arab Uprisings and the International Oil Markets', Chatham House Briefing Paper, EERG 2012/03, February 2013, available at

www.chathamhouse.org/sites/default/files/public/Research/Energy,\%20Environment\%20and\%20Dev elopment/bp0212stevens.pdf (retrieved January 2014).

${ }^{5}$ BP (2013) Statistical Review of World Energy 2013. Available online at

www.bp.com/en/global/corporate/about-bp/energy-economics/statistical-review-of-world-energy2013.html (retrieved March 2014).

${ }^{6}$ There is a wealth of literature on each of these subjects. IEA (2012); and IEA (2013); as well as OPEC (2013) provide thorough summaries of the various factors at play. IEA (2013), World Energy Outlook, Paris-Cedeux: International Energy Agency; EIA (2013), International Energy Outlook 2013, Energy Information Administration, available at www.eia.gov/forecasts/ieo/pdf/0484(2013).pdf (retrieved January 2014); OPEC (2013), Annual Report 2013, Vienna: Organization of the Petroleum Producing and Exporting Countries.

${ }^{7}$ The Gulf Cooperation Council (GCC) is composed of Bahrain, Kuwait, Oman, Qatar, Saudi Arabia, and the United Arab Emirates (UAE).

${ }^{8}$ For a background to Egypt's post-Mubarak transitional period, see Brown, N.J. (2013), 'Tracking the Arab Spring: Egypt's Failed Transition', Journal of Democracy 24:4, October 2013, 45-58; El-Sherif, A. (2014), 'Egypt's Post-Mubarak Predicament', Carnegie Endowment for International Peace, Washington D.C.

Available online at http://carnegieendowment.org/files/post mubarak predicament.pdf (retrieved February 2014).

${ }^{9}$ Syrian Regional Refugee Response Inter-agency Information Sharing Portal, UNHCR (accessed on 28 January 2014) 
${ }^{10}$ See 'Syria: War on three fronts', MEES 56:29, 19 July 2013; 'Lebanon on the Brink', MEES 56:33, 16 August 2013.

${ }^{11}$ The US Congressional Research Service provides a detailed overview over the situation at the time. See Blanchard, C.M., Humud, C.E., and Nikitin, M.B.D. (2014), 'Armed Conflict in Syria: Overview and U.S. Response', CRS Report, Congressional Research Service, available at www.fas.org/sgp/crs/mideast/RL33487.pdf (retrieved January 2014). See also 'Syria: Will the US intervene or not?' MEES 56:36, 6 September 2013.

${ }^{12}$ Syrian oil trade with the EU and Turkey accounts for around $99 \%$ of total Syrian crude oil exports. Small-scale alternative trades (mainly in the form of barter trade of crude oil for products) have been reported, such as with Russia, at ranges of around 33,000 barrels/d. EIA (2014) Syria Country Analysis Brief, downloaded from www.eia.gov/countries/cab.cfm?fips=SY (retrieved January 2013). Data based on EIA (2014) International Energy Data. Available online database at www.eia.gov/cfapps/ipdbproject/IEDIndex3.cfm (retrieved January 2013). See also our discussion below in Section 2.2.

${ }^{13}$ See our discussion in Section 3 below.

${ }^{14}$ Yemen's oil revenues have accordingly plummeted over the past years. E.g. see 'Yemen Oil Revenues take Nosedive', MEES 56:25, 21 June 2013; See also IMF (2012), Republic of Yemen December 2012 Staff Visit: Mission Concluding Statement, Washington D.C.: International Monetary Fund, 9 December 2012.

${ }^{15}$ The most recent attack at the time of writing occurred at the beginning of January 2014. 'Egypt prosecutors investigate Sinai gas pipeline bombing', Al-Ahram online, 1 January 2014. MEES counted 16 pipeline attacks between the overthrow of the Mubarak regime in January 2011 and July 2013. 'Blast Shuts Egypt-Jordan Pipeline', MEES 56:28, 12 July 2013.

${ }_{17}^{16}$ BBC News, 'Algeria Siege: 37 Foreigners Died, PM Says', 21 January 2013.

${ }^{17}$ For a reflection on the In Amenas attacks, see Ali Aissaoui, 'AIG Symposium: Thoughts on In Amenas', op-ed, MEES, 22 February 2013; Hagen's Report, 'The In Amenas Attack - Investigation into the Terrorist Attack on In Amenas', Statoil, 12 September 2013. The authors thank Ali Aissaoui for his useful comments on this point.

${ }^{18}$ Authors' estimates, based on an average of the monthly third-party estimates included in monthly publications by the IEA (Oil Market Report), the EIA (Short Term Energy Outlook) and the OPEC Secretariat (Monthly Oil Market Report) along with surveys published by Reuters, Bloomberg, MEES, and Platts. For the remainder of this paper, we refer to this as the 'OPEC supply estimate'.

${ }^{19}$ For instance, Blas, J., 'Iran worries spark fears of $\$ 200$-a-barrel oil', Financial Times, 8 November 2011. This is a recurring theme in forecasting associated to the threat of disruption to oil supplies from the MENA region, for example see Smith, G., 'Oil may surge to \$220 if Libya, Algeria halt, Nomura says', Bloomberg, 23 February 2011.

${ }^{20}$ El-Katiri, L. and Fattouh, B. (2012), 'On Oil Embargos and the Myth of the Iranian Oil Weapon', Oxford Energy Comment, February 2012. See also Khalaf, R. and Blitz, J. 'Strain in the Strait', Financial Times, 23 January 2012; 'Dire Straits', LNG Intelligence, 11 January 2011.

${ }^{21}$ Data based on BP (2013); Aissaoui, A., 'Strait of Hormuz: Alternate Oil Routes Not Enough', op-ed, MEES, 26 October 2012

${ }^{22}$ Aissaoui, A. 'Strait of Hormuz: Alternate Oil Routes Not Enough', op-ed, MEES, 26 October 2012.

${ }^{23}$ Luciani (2011) traces the development of Iraq's oil production throughout the two Gulf wars and the US invasion of 2003. Luciani, G. (2011) 'Armed Conflicts and Security of Oil and Gas Supplies CEPS Working Document' No.352, Centre for European Policy Studies, downloaded from www.ceps.eu/book/armed-conflicts-and-security-oil-and-gas-supplies (retrieved March 2014). See also previous publications, including Luciani, Giacomo (1989), 'Oil and Instability: The Political Economy of Petroleum and the Gulf War', in H. Maull and O. Pick, The Gulf War: Regional and International Dimensions, London: Pinter; Khadduri, Walid (2004), 'Iraq: Future of the Oil Industry', in 
C.P. Hanelt, G. Luciani, and F. Neugart (eds), Regime Change in Iraq: the Transatlantic and Regional Dimensions, EUI and Bertelsmann Stiftung.

${ }^{24}$ Luciani (2011) op. cit., 9-10.

${ }^{25}$ See Figure 8 Section 3.2. below.

${ }^{26}$ Ibid.

${ }^{27}$ Authors' calculations based on OPEC supply estimates and Libyan production capacity standing at 1.59 million b/d prior to the 2011 revolution.

${ }^{28}$ Oil Minister Suleiman al-Abbas quoted by state news agency SANA. 'Syria oil output dives 96 percent: minister', The Daily Star, 16 February 2014.

${ }^{29}$ EIA (2014) Syria Country Analysis Brief. Available at: www.eia.gov/countries/cab.cfm?fips=SY\&scr=email (retrieved February 2014).

${ }^{30}$ Authors' calculations based on EIA International Energy Statistics.

${ }^{31}$ Gulf aid has so far taken several forms, principally direct grants, loans, in-kind aid in the form of refined products, LNG cargoes, and the conclusion of an agreement on Saudi-Egyptian electricity trade, to materialize in the coming years. 'Gulf States Finalize Rescue Package For Egypt', MEES 56:28, 12 July 2013; 'Egypt Receives Gulf Aid But Qatar Backs Off', MEES 56:39, 27 September 2013; 'Saudi-Egypt Power Link Deal Signed, But GCC Grid Usage "Minimal”', MEES 56:23, 7 June 2013.

32 'Iraq: No End In Sight To Attacks On Northern Export infrastructure', MEES 56:44, 1 November 2013.

${ }^{33}$ 'Iraq Achieves 2013 Oil Output Target But Exports Still Constrained', MEES 57:1, 3 January 2014; Razzouk, N., 'Iraq threatens to cut revenue to Kurds over pipeline', Bloomberg, 24 September 2013.

${ }^{34}$ Authors' calculation based on OPEC supply estimates. Calculations take output levels prior to the current disruptions as a baseline for calculating lost output volumes. The figures used are: Iran: 3.59 million b/d; Libya: 1.59 million b/d; Yemen: 0.25 million b/d; and Syria: 0.4 million b/d. A recent update on the situation of Iranian sanctions and the results of the November 2013 talks can be found at IAEA (2013), Implementation of the NPT Safeguards Agreement and relevant provisions of Security Council resolutions in the Islamic Republic of Iran. IEA Board Report, November 2013, available online at www.iaea.org/newscenter/focus/iaeairan/iaea reports.shtml (retrieved January 2014).

${ }^{35}$ EIA (2014) International Energy Data. Available online database at www.eia.gov/cfapps/ipdbproject/IEDIndex3.cfm (retrieved January 2013); See also 'Brent higher amid unrest in South Sudan, Libya', Reuters, 30 December 2013.

${ }^{36}$ The risk of Brent prices reaching $\$ 200$ per barrel kept resurfacing in media outlets and price forecasts throughout 2011 and 2012. For instance, Blas, J., 'Iran worries spark fears of \$200-a-barrel oil', Financial Times, 8 November 2011.

${ }^{37}$ OPEC supply estimates.

${ }^{38}$ Authors' calculations based on OPEC supply estimates.

${ }^{39}$ Energy Aspects calculations.

${ }^{40}$ See Darbouche and Fattouh (2011) op.cit., 29.

41 'Militants Attack Yemen LNG Pipeline, Stop Production Of Four Cargoes', MEES 55:15, 9 April 2012.

${ }^{42}$ Authors' calculations based on data from Enagas and SNAM.

${ }^{43}$ Darbouche and Fattouh (2011), op. cit., 29-31; 'ENI sees Q2 earnings fall 31\% on Libya', European Gas Daily, 1 August 2011; 'Greenstream link suspended, but traders remaining calm', European Gas Markets, 28 February 2011; 'Libya's misfortunes benefit ENI and Gazprom', Gas Matters, March 2011.

${ }^{44}$ This view has also been confirmed by BP's most recent 2014 Energy Outlook, which sees the MENA economies emerge over the next two decades as the world's most gas-intensive region. See BP (2014) Energy Outlook. Available online at www.bp.com/en/global/corporate/about-bp/energyeconomics/energy-outlook.html (retrieved January 2014). 
45 'Saudi Arabia Unveils Record 2014 Budget Despite Curb On Expenditure Growth', MEES 57:1, 3 January 2014.

46 'Kuwait Budget Surplus Falls As Spending Soars', MEES 56:36, 6 September 2013; 'Kuwait Budget Surplus Falls In First Half 2013-14', MEES 57:2, 10 January 2014.

${ }^{47}$ Alas, N. and Parkinson, J., 'Gulf States Plan Aid Package for Bahrain, Oman', Wall Street Journal, 3 March 2011; 'Gulf signs off \$20bn aid deal for Oman, Bahrain', Arabian Business, 1 March 2011.

${ }^{48}$ The GCC states' governmental spending is publically accessible via the relevant finance ministries. For instance, see SAMA (2013) $49^{\text {th }}$ Annual Report - Latest Economic Developments 1434H/2013G, Riyadh, SA: Saudi Arabian Monetary Agency. Available online at www.sama.gov.sa/sites/SAMAEN/ReportsStatistics/Pages/AnnualReport.aspx (retrieved January 2014).

${ }^{49}$ See fn 31

50 'OPEC Producers Adopt Higher Oil Price Assumptions for 2013 Budgets', MEES 56:30, 26 July 2013; 'Kuwait sees 2014/15 budget expenditure of $\$ 77$ billion - KUNA', Reuters, 23 January 2014; and 'Iran tries to regain status as oil power', Khadduri, W., Al-Monitor, 17 February 2014.

${ }^{51}$ Aissaoui, A., 'Modeling OPEC Fiscal Break-even Oil Prices: New Findings and Policy Insights', APICORP Economic Commentary Vol.8 No.9-10, September-October 2013, in: APICORP (2013) Wrapping Up Volume 8, 2013, December 2013, 38.

${ }^{52}$ See also Stournaras, Y. (1984), 'Depletion Policies for Oil-Exporting Countries', OIES Working Paper WPM2, Oxford: Oxford Institute for Energy Studies. In 2010 King Abdullah of Saudi Arabia said that the country would halt oil exploration so that reserves could be preserved for future generations. ${ }^{53}$ E.g. see Carmignani, F. (2003), 'Political Instability, Uncertainty and Economics', Journal of Economic Surveys, 17:1, 1-54.

${ }^{54}$ Also see Fattouh, B. and El-Katiri, L. (2012), 'Energy Subsidies in the Arab World', Arab Human Development Report Research Paper Series, United Nations Development Programme, 2012.

55 'Egypt: Fuel Subsidies Remain Pressing Economic Issue', MEES 56:27, 5 July 2013; 'Gulf States Finalize Rescue Package For Egypt', MEES 56:28, 12 July 2013.

${ }^{56}$ For more detailed discussion, see Fattouh and El-Katiri (2012), op. cit.

57 'Petroleum Products Subsidies To Reach \$12Bn, Fahmy Says', MEES 53:3, 11 January 2010; 'Bahrain Braced For Increase In Domestic Gas Price', MEES 54:40, 3 October 2011; 'Oil Producers See Budgets Pressured By Social Unrest, Crude Dip', MEES 54:33, 15 August 2011.

58 'Qatar Sends Egypt Free LNG', MEES 56:34, 23 August 2013.

${ }^{59}$ See our discussion in Section 2.1 above.

${ }^{60}$ The latest in a series of companies to rethink their projects amid growing instability is BP, which recently announced that it had mothballed plans to explore in Libya's Ghadames basin because of security concerns. 'BP shelves onshore exploration in Libya as instability grows', Reuters, 6 March 2014.

61 'Gunmen shoot dead 18 oil workers in northeast Iraq', Reuters, 13 December 2013.

62 'Angola's Sonangol to pull out of two oilfields in Iraq', Reuters, 25 February 2014.

${ }^{63}$ A number of good quality reports discuss Yemen's continuing unstable domestic political situation in great depth. See, for instance, Hill, J., Salisbury, P., Northedge, L. and Kinninmont, J. (2013), 'Yemen. Corruption, Capital Flight and Global Drivers of Conflict', Chatham House Report, available at www.chathamhouse.org/sites/default/files/public/Research/Middle\%20East/0913r yemen.pdf (retrieved January 2014); Hill, J. and Nonneman, G. (2011), 'Yemen, Saudi Arabia and the Gulf States: Elite Politics, Street Protests and Regional Diplomacy', Chatham House Briefing Paper, available at www.chathamhouse.org/sites/default/files/19237 0511yemen gulfbp.pdf (retrieved January 2014); Sharqieh, I. (2013), 'A Lasting Peace? Yemen's Long Journey to National Reconciliation', Brookings Doha Center Analysis Paper Number 7, February 2013, available at www.brookings.edu/ /media/research/files/papers/2013/02/11\%20yemen\%20national\%20reconciliati on\%20sharqieh/bdc yemen\%20national\%20reconciliation sharqieh.pdf (retrieved January 2014). 
${ }^{64}$ Aissaoui, A., 'MENA Lingering Turmoil and its Effect on Energy Investment Climate: A Reassessment', APICORP Economic Commentary, Vol.8 No.12, December 2013.

${ }^{65}$ Luciani (2011), op. cit. provides a good overview over these events.

${ }^{66}$ Cockayne, J., 'Payment delays turn independents away from Egypt', MEES 55:42, 12 October 2012.

${ }^{67}$ On Egypt's natural gas sector's situation, see Aissaoui, A., 'Between a Rock and a Hard Place: Egypt's New Natural Gas Supply Policy', APICORP Economic Commentary, Vol.8 No.3, March 2013. ${ }^{68}$ El-Katiri, M. (2014 forthcoming), 'Revival of Political Islam in the Aftermath of the Arab Uprisings: Implications for the Region and Beyond', Carlisle, PA: US Army War College, Strategic Studies Institute.

${ }^{69}$ For a detailed update of Syria's hydrocarbon sector as of January 2014, see EIA (2014) Syria Country Analysis Brief. Available at: www.eia.gov/countries/cab.cfm?fips=SY\&scr=email (retrieved February 2014).

${ }^{70}$ Shortly after the overthrow of Saddam Hussein, the Coalition Provisional Authority set a target to rapidly increase production to 2.5 million b/d and interim Iraqi leaders discussed a target of 8 million b/d by 2010. By 2004 it was clear that this long-term target was unachievable and it was moderated to 6 million b/d by the Ministry of Oil. Despite being far from that target by 2010 , the signature of new production contracts led the government to set a production target of 12.5 million b/d by 2017. Delays to projects and infrastructural bottlenecks made some of the chronic challenges more visible and as fields continued to miss their target dates for first commercial production, the 12.5 million b/d target was lowered to 10 million b/d and delayed to 2020 , and then subsequently lowered to 9 million b/d, where it stands currently. See Alhajji, A., 'Expansion of Iraq's Oil Production Capacity: The Challenges Ahead', MEES 46:27, July 2003; Zainy, M., 'Iraq's Oil Sector: Scenarios for the Future', MEES 47:42, October 2004; Chalabi, F., 'Iraq's Oil Expansion and Market Stability', MEES 53:49, December 2010; and 'Iraqi oil: A hard tap to turn', The Economist, March 2013.

${ }^{71}$ Kuwait's most recent oil ministry reshuffle followed the resignation of previous Oil Minister Hani Hussein in May 2013 under pressure from parliament. Kuwait's current Oil Minister Mustapha AlShamali was first caretaker of the role until the July 2013 new elections. These events follow Kuwait's 2012 parliamentary crisis, which deadlocked Kuwait's parliament for nearly a year, beginning itself with the fourth parliamentary election in five years.

${ }^{72}$ Examples in Kuwait's upstream sector development are extensive. Previous Oil Minister Sheikh Ahmad al-Abdullah al-Sabah was said to entertain strained relations towards Kuwait Petroleum Company (KPC), whose board's preferred candidate had been passed over in the appointment of the Oil Minister in September 2010. Appointment of the Oil Minister has also played at various times into existing conflicts between different parliamentarians. One of Kuwait's landmark agreements, aimed at raising the country's upstream capacity natural gas reserves with Royal Dutch Shell, has been under parliamentary investigation since it was signed in 2010. More recently, in November 2013, Kuwait withdrew from a flagship offshore oil and gas project in the Neutral Zone shared with Saudi Arabia, in what has been described as 'the political inertia that has been a feature of Kuwaiti governance for the best part of a decade, as well as to the recent reshuffle within the state-owned oil sector following yet another cabinet change and the appointment of a new oil minister.' 'Kuwait Withdraws From Key Neutral Zone Project', MEES 56:47, 22 November 2013. See also 'Kuwait: Looking for Leadership', Energy Compass, 10 December 2010; 'Kuwait: Paralysis Prolonged', Energy Compass, 27 August 2010.

${ }^{73}$ IEA (2005), World Energy Outlook 2005, Paris-Cedeux: International Energy Agency.

${ }_{75}^{74}$ IEA (2013), World Energy Outlook 2013, Paris-Cedeux: International Energy Agency, 458ff.

${ }^{75}$ E.g. Daragahi, B., 'Libya's oil production hostage to political unrest', Financial Times, 18 November 2013.

${ }^{76}$ For instance, see Malik, A. and Awadallah, B. (2011), 'The Economics of the Arab Spring', Oxford: Oxford University, Center for the Study of African Economies; Springborg, R. (2011), 'The Political Economy of the Arab Spring', Mediterranean Politics, 16:3, 427-33; Campante, F.R. and Chor, D. 
(2012), 'Why was the Arab World Poised for Revolution? Schooling, Economic Opportunities, and the Arab Spring', The Journal of Economic Perspectives, Vol. 26, No. 2 (Spring 2012), 167-87.

${ }^{77}$ Hill et al (2013) op. cit., 19-22.

${ }^{78}$ Key factors taken into consideration in the survey include government vision, and the practical articulation of that vision into legislation, regulation, and the fiscal regime. In the financial sector, considerations include the country's financial structures, the degree of development and performance of the capital market, as well as the extent to which the business climate in each country has been conducive to project financing (meaning non- or limited-recourse financing). Aissaoui, A., 'MENA Lingering Turmoil and its Effect on Energy Investment Climate: A Reassessment', APICORP Economic Commentary Vol. 8 No 12, December 2013, 2.

${ }^{79}$ Examples include Libya, Egypt, Syria, Iraq, and Yemen. The recent, major investment reviews by US independent Occidental Petroleum of its MENA assets has been interpreted by some analysts as being partly inspired by heightened project costs in response to the worsening security situation in some of Oxy's key MENA asset positions, including Libya, Yemen, and Iraq. 'Occidental Eyes Sale Of All Mideast Assets', MEES 56:23, 7 June 2013.

${ }^{80}$ Luciani (2011) op. cit., 1. 